\title{
Phylogenetic Species Recognition and hybridisation in Lasiodiplodia: A case study on species from baobabs
}

\author{
Elsie M. Cruywagen ${ }^{\mathrm{a}}$, Bernard Slippers ${ }^{\mathrm{b}}$, Jolanda Roux ${ }^{\mathrm{a}}$ and Michael J. Wingfield ${ }^{\mathrm{a}}$ \\ ${ }^{a}$ Department of Plant and Soil Sciences, DST-NRF Centre of Excellence in Tree Health Biotechnology (CTHB), \\ Forestry and Agricultural Biotechnology Institute (FABI), Faculty of Natural and Agricultural Sciences, \\ University of Pretoria, Pretoria, South Africa \\ ${ }^{\mathrm{b}}$ Department of Genetics, CTHB, FABI, University of Pretoria, Pretoria, South Africa \\ elsie.cruwyagen@fabi.up.ac.za, bernard.slippers@fabi.up.ac.za, jolanda.roux@fabi.up.ac.za, \\ mike.wingfield@fabi.up.ac.za
}

Corresponding author: Bernard Slippers, Tel: +2712 420 3938, Fax: +2712 420 3960, Postal address: FABI, University of Pretoria, Private bag X20, Hatfield, 0028, South Africa

\section{Highlights}

- Hybridisation is occurring frequently in Lasiodiplodia.

- Lasiodiplodia brasiliense, Lasiodiplodia laeliocattleyae, Lasiodiplodia missouriana, and Lasiodiplodia viticola are hybrids.

- Ten Lasiodiplodia species were identified from baobab trees in Africa.

\begin{abstract}
Lasiodiplodia species (Botryosphaeriaceae, Ascomycota) infect a wide range of typically woody plants on which they are associated with many different disease symptoms. In this study, we determined the identity of Lasiodiplodia isolates obtained from baobab (Adansonia species) trees in Africa and reviewed the molecular markers used to describe Lasiodiplodia species. Publicly available and newly produced sequence data for some of the type strains of Lasiodiplodia species showed incongruence amongst phylogenies of five nuclear loci. We conclude that several of the previously described Lasiodiplodia species are hybrids of other species. Isolates from baobab trees in Africa included nine species of Lasiodiplodia and two hybrid species. Inoculation trials with the most common Lasiodiplodia species collected from these trees produced significant lesions on young baobab trees. There was also variation in aggressiveness amongst isolates from the same species. The apparently widespread tendency of Lasiodiplodia species to hybridise demands that phylogenies from multiple loci (more than two and preferably four or more) are compared for congruence prior to new species being
\end{abstract}


described. This will avoid hybrids being incorrectly described as new taxa, as has clearly occurred in the past.

\section{Keywords}

Phylogenetic species concept, Botryosphaeriaceae, fungal hybrids, barcoding, taxonomy

\section{Introduction}

Species represent the basic units of taxonomy. However, decisions on how to define species boundaries, especially in fungi, are often problematic. Three species concepts are most commonly applied in fungal taxonomy, namely the Morphological (MSR), Biological (BSR) and Phylogenetic Species Recognition (PSR) concepts (Taylor et al. 2000) and all three present some challenges. Historically, fungal taxonomy has relied on the MSR concept, where species were described only when they could be distinguished based on distinct morphological characteristics (Taylor et al. 2000). The advent of DNA sequencing and an ability to apply phylogenetic inference has shown clearly that MSR has substantially underestimated the global fungal diversity (Crous et al. 2006; Schoch et al. 2014).

The BSR concept postulates that individuals of different species should be reproductively isolated (Taylor et al. 2000). However, there are growing numbers of examples where different species of fungi are able to cross and effectively reproduce to form hybrids. For example, a viable interspecies hybrid of Fusarium circinatum and $F$. subglutinans has been produced under laboratory conditions (De Vos et al. 2011). Other examples include the hybrid poplar rust Melampsora $\times$ columbiana, which is a natural hybrid of M. medusae and $M$. occidentalis (Newcombe et al. 2000), and the hybrids between the white pine blister rust Cronartium ribicola and C. comandrae (Joly et al. 2006). An additional problem with the BSR concept is the fact that many fungi are known only in their asexual states and it is not possible to determine whether they are able to reproduce sexually.

The PSR concept, and more specifically the Genealogical Concordance Phylogenetic Species Recognition (GCPSR) concept, is increasingly widely used to delineate species of fungi. This approach relies on determining the concordance between multiple gene genealogies and delimiting species where the branches of multiple trees display congruence (Taylor et al. 
2000). The GCPSR ensures that species are not described based on small differences arising from within taxon variation.

The PSR has been widely applied during the last decade to describe cryptic species that could not be identified using the MSR. One example where a number of cryptic species have been described is in Lasiodiplodia, a common genus in the Botryosphaeriaceae (Phillips et al. 2013). The type species of this genus, L. theobromae, has been reported from more than 500 plant species (Punithalingam 1976). This was, however, before the advent of DNA sequencebased identification (Alves et al. 2008; Pavlic et al. 2004; Pavlic et al. 2009; Phillips et al. 2013; Slippers et al. 2004). For many years L. theobromae was the only species in Lasiodiplodia, but 28 additional species have been described since 2004, based on both DNA sequence data and morphological characteristics (Abdollahzadeh et al. 2010; Alves et al. 2008; Begoude et al. 2010; Burgess et al. 2006; Chen et al. 2015; Damm et al. 2007; Ismail et al. 2012; Linaldeddu et al. 2015; Liu et al. 2012; Machado et al. 2014; Netto et al. 2014; Pavlic et al. 2004; Pavlic et al. 2008; Prasher and Singh ; Trakunyingcharoen et al. 2015; Urbez-Torres et al. 2012). It has also become clear that some of the reports of $L$. theobromae prior to 2004 represent other species of Lasiodiplodia and a new list of host species for this fungus is required.

Lasiodiplodia plurivora was the first cryptic species to be described in Lasiodiplodia (Damm et al. 2007), based on sequence variation in the internal transcribed spacer of the rDNA (ITS) and translation elongation factor-1 $\alpha(t e f 1-\alpha)$ regions. Shortly thereafter Alves et al. (2008) described L. parva and L. pseudotheobromae using the same loci. Subsequently, 20 additional species have been described in the L. theobromae complex. The majority of the 24 species that are now known in this complex cannot be identified based on morphology alone. Five species consistently group outside the L. theobromae species complex, namely $L$. crassispora, L. gonubiensis, L. pyriformis, L. rubropurpurea and L. venezuelensis (Burgess et al. 2006; Pavlic et al. 2004; Slippers et al. 2014).

The PSR concept provides the most powerful means to distinguish between taxa, also in terms of practical uses in quarantine and disease management. Unfortunately this approach is not without problems, especially where only a few loci are used. For example, hybridisation cannot always be recognised if sequences of only one (and often even two loci) have been considered. This is an important consideration because many fungi have the capacity to hybridize through sexual reproduction or exchange genetic material through anastomosis 
(fusion) of their vegetative hyphae in a parasexual cycle (Olson and Stenlid 2002; Schardl and Craven 2003; Stukenbrock 2016).

There are different possible outcomes of hybridisation in fungi, but only the two outcomes most applicable to this study will be discussed. The first and probably most common is introgression, where the hybrids in the population transfer novel genes to the parent population through backcrosses and the hybrid isolates eventually disappear from the population (Brasier 1995). The second outcome is the establishment of hybrid species that remain stable in the environment (Brasier 1995). These species are then described as nothospecies and indicated as hybrids with the symbol " $\times$ " as was done for $M \times$ columbiana (Newcombe et al. 2000), Phytophthora $\times a l n i$, P.×multiformis (Husson et al. 2015) and P.xpelgrandis (Nirenberg et al. 2009). It is important to indicate when a new species being described is a hybrid as these species can cause incongruence between different trees of different loci (Schardl and Craven 2003).

Lasiodiplodia occurs globally on woody plants in the tropics and sub-tropics (Punithalingam 1976). Species in the genus have been associated with many different plant diseases including fruit and root rots, die-back of branches and stem cankers (Burgess et al. 2006; Ismail et al. 2012; Sakalidis et al. 2011a; Urbez-Torres et al. 2012). Lasiodiplodia species have many different plant hosts, but pertinent to this study, they are also well-known on the iconic Baobab (Adansonia species), native to Africa and Australia (Roux 2002; Sakalidis et al. 2011a). In pathogenicity tests on the Australian baobab (Adansonia gregorii), L. iraniensis and L. mahajangana were shown to cause bark lesions and root rot (Sakalidis et al. 2011a).

The aims of this study were to identify species of Lasiodiplodia on baobab trees in Africa and to assess their ability to cause disease. We also evaluated the suitability of using sequence data from different nuclear loci for species delimitation in Lasiodiplodia. Using this information, all species in the genus were reassessed. The possible occurrence of hybrid Lasiodiplodia isolates from baobab trees, as well as in the previously described species was a specific focus. 


\section{Materials and Methods}

\subsection{Sample collection and isolations}

South Africa. Plant tissue samples from which to isolate endophytic Botryosphaeriaceae from baobab trees (A. digitata s.l.) were collected during three surveys conducted in the Limpopo Province of South Africa (Fig 1, Table 1). The first collections were made in the Soutpansberg and Musina areas in June 2007 and this was followed by sampling in the Venda area and Kruger National Park (KNP) in February 2009. A third collection was made in April 2010 and this extended from the Musina area towards the west and south. Endophyte isolations from the first collection trip were made after surface disinfestation of branch tissue with $5 \% \mathrm{HOCl}$, rinsing in sterile distilled $\mathrm{H}_{2} \mathrm{O}$, disinfesting with $70 \% \mathrm{EtOH}$ and again rinsing in sterile distilled $\mathrm{H}_{2} \mathrm{O}$, each for one minute. Branch samples were then cut into approximately 5 x $5 \mathrm{~mm}$ pieces and plated onto $2 \%$ MEA amended with streptomycin.

Surface disinfestation of samples collected during the second and third surveys was done by immersing plant tissue in $5 \% \mathrm{H}_{2} \mathrm{O}_{2}$ for five minutes, followed by rinsing three times in sterile $\mathrm{H}_{2} \mathrm{O}$ for one minute each, after which the samples were cut and plated as described above.
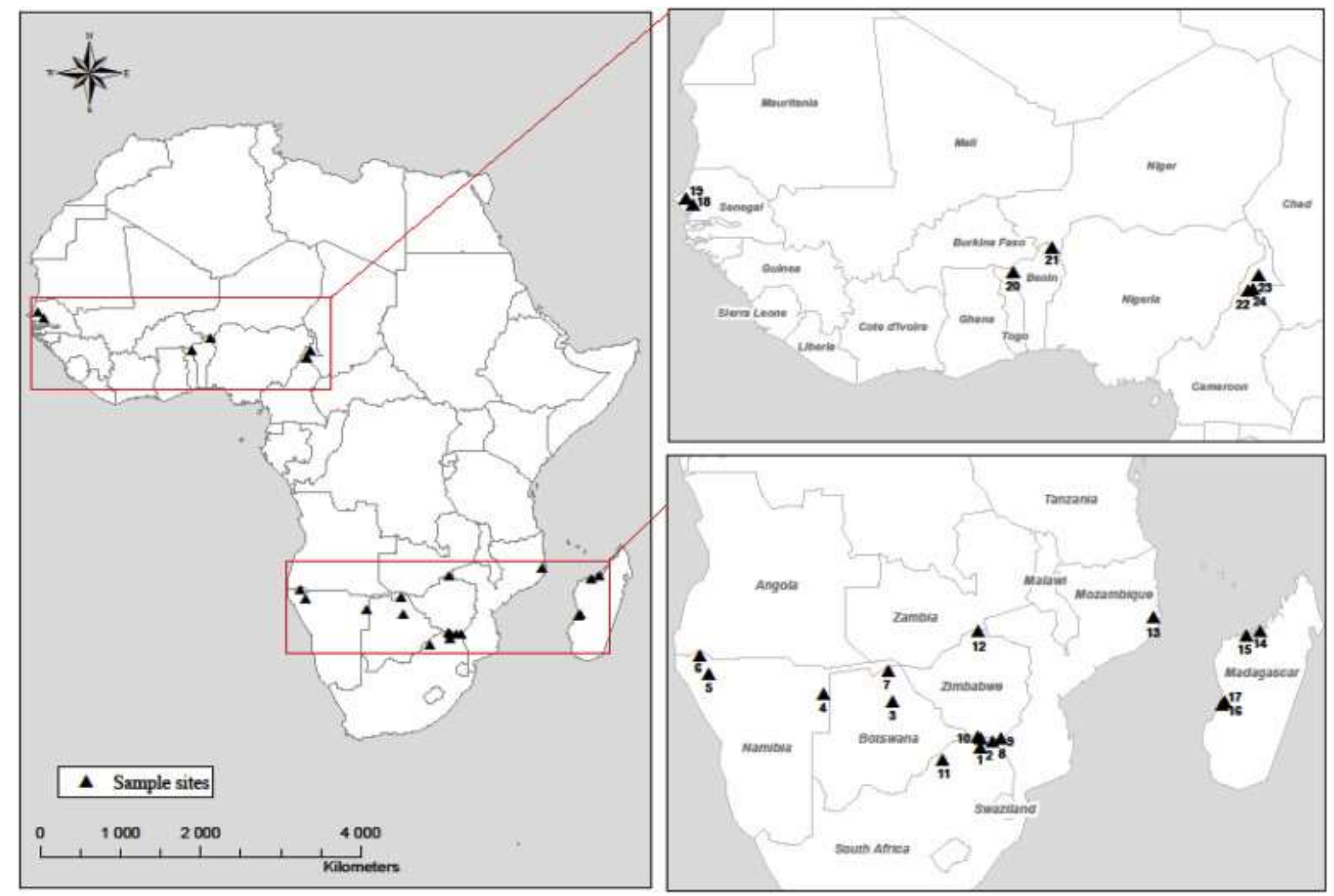

Fig 1 Map of Africa, indicating areas sampled in southern Africa, West Africa and Madagascar. Numbers of sample areas correspond to column 3 in Table 1 
Table 1 Samples collected from baobab trees in southern Africa, West Africa and Madagascar

\begin{tabular}{|c|c|c|c|c|c|}
\hline Date & Country & $\begin{array}{l}\text { Area on map } \\
\text { (Fig 1) }\end{array}$ & $\begin{array}{l}\text { Nr. of trees } \\
\text { sampled }\end{array}$ & Twigs / Bark & Diseased / Healthy \\
\hline June 2007 & South Africa - Musina & $1 ; 2$ & 37 & Twigs & Some discolouration in wood \\
\hline Sept. 2007 & Botwsana - Nxai pan & 3 & 9 & Twigs & Healthy \\
\hline Oct. 2007 & Namibia - Tsumkwe & 4 & 14 & Twigs & Many diseased \\
\hline \multirow[t]{3}{*}{ Oct. 2007} & Namibia - Joubert mountains & 5 & 32 & Twigs & Healthy \\
\hline & Namibia - Epupa & 6 & 5 & Twigs & Healthy \\
\hline & Botswana - Chobe & 7 & 3 & Twigs & Stressed \\
\hline \multirow[t]{5}{*}{ Oct. 2007} & Madagascar - Andranoboka $*^{1}$ & 14 & 15 & Twigs \& bark & Not visibly diseased \\
\hline & Madagascar - Antseza & 15 & 18 & Twigs \& bark & Not visibly diseased \\
\hline & Madagascar - Morondava $*^{2}$ & 17 & 16 & Bark & Not visibly diseased \\
\hline & Madagascar - Andranomena $*^{3}$ & 16 & 20 & Bark & Not visibly diseased \\
\hline & Madagascar - Andranomena $*^{4}$ & 16 & 8 & Bark & Not visibly diseased \\
\hline \multirow[t]{4}{*}{ Jan. 2008} & Senegal - Fatick & 18 & 1 & Twigs \& bark & Healthy \\
\hline & & & 6 & Twigs \& bark & Diseased \\
\hline & Senegal - Thies & 19 & 3 & Twigs \& bark & Healthy \\
\hline & & & 15 & Twigs \& bark & Diseased \\
\hline \multirow[t]{2}{*}{ Feb. 2008} & South Africa - Venda & 8 & 14 & Twigs & Mostly healthy \\
\hline & $\begin{array}{l}\text { South Africa - Kruger National } \\
\text { Park }\end{array}$ & 9 & 31 & Bark & Elephant damage \\
\hline \multirow[t]{3}{*}{ Aug. 2008} & Benin - Materi & 20 & 3 & Twigs \& Bark & Diseased \\
\hline & Benin - Bogo bogo & 21 & 1 & Bark & Healthy \\
\hline & Benin & & 10 & Twigs \& Bark & Diseased \\
\hline \multirow[t]{3}{*}{ Dec. 2009} & Cameroon - Solawel/Figuil & 22 & 4 & Bark & Healthy \\
\hline & Cameroon - Maroua & 23 & 9 & Bark & Healthy \\
\hline & Cameroon - Lombel & 24 & 21 & Bark & Healthy \\
\hline \multirow[t]{3}{*}{ Apr. 2010} & South Africa - Musina area & 2 & 41 & Bark & Healthy \\
\hline & South Africa - Musina-Alldays & 10 & 9 & Bark & Healthy \\
\hline & South Africa - Lephalale & 11 & 5 & Bark & Healthy \\
\hline July 2010 & Zimbabwe - Hurungu \& Chewore & 12 & 10 & Bark & Healthy \\
\hline Aug. 2010 & Mozambique - Monapo & 13 & 6 & Bark & Healthy \\
\hline
\end{tabular}

* Adansonia species sampled not A. digitata, ${ }^{1}$ A. madagascariensis, ${ }^{2}$ A. grandidieri, ${ }^{3}$ A. rubrostipa, ${ }^{4}$ A. $z a$ 
Botswana and Namibia. Branch samples were collected from 12 and 51 A. digitata s.l. trees in Botswana and Namibia, respectively (Fig 1, Table 1), from September - October 2007. Isolations for endophytic fungi were made after surface disinfestation with $\mathrm{HOCl}$ and $\mathrm{EtOH}$ as described above.

Madagascar. During October 2007, branch and bark samples were collected from five of the seven species of baobab trees occurring in Madagascar. Samples were collected from 77 trees (Fig 1, Table 1) and endophyte isolations were made after surface disinfestation with 5\% $\mathrm{H}_{2} \mathrm{O}_{2}$.

Cameroon. In December 2009, branch and bark samples were collected from 34 baobab trees in three areas in Cameroon (Fig 1, Table 1) and endophytic fungi were isolated as described above after surface disinfestation with $5 \% \mathrm{H}_{2} \mathrm{O}_{2}$.

Benin and Senegal. Bark and branch samples were obtained from Dr. Aida Cuni Sanchez in January and August 2008 from Senegal and Benin (Fig 1, Table 1). Endophytic fungi were isolated from these samples after surface disinfestation with $5 \% \mathrm{H}_{2} \mathrm{O}_{2}$, as described above.

Zimbabwe. Bark samples were collected from ten baobab trees from the northern part of the country during July 2010. Endophytic fungi were isolated from these samples after surface disinfestation with $5 \% \mathrm{H}_{2} \mathrm{O}_{2}$, as described above.

Mozambique. During August 2010, bark samples were collected from six baobab trees. Endophytic fungi were isolated from these samples after surface disinfestation with $5 \% \mathrm{H}_{2} \mathrm{O}_{2}$, as described above.

Plates (MEA) were incubated at $25{ }^{\circ} \mathrm{C}$ for seven days and checked daily for fungal growth. Pure cultures were made by transferring hyphal tips of the fungi appearing to represent the Botryosphaeriaceae to clean MEA plates. Selected isolates from each region were deposited in the culture collection (CMW) of the Forestry and Agricultural Biotechnology Institute (FABI), University of Pretoria, South Africa.

\subsection{DNA extraction, PCR amplification and sequencing}

Available isolates of previously described Lasiodiplodia species (Table 2) were obtained for this study. Isolates of five species described from Brazil (L. brasiliense, L. euphorbiicola, $L$. jatrophicola, L. macrospora and L. subglobosa) and one species from India (L. indica) could not be obtained. Isolates of two species that were described during 2015, were also not 
Table 2 Isolates of existing Lasiodiplodia species included in analyses

\begin{tabular}{|c|c|c|c|c|c|c|c|c|c|c|}
\hline \multirow[b]{2}{*}{ Species } & \multirow[b]{2}{*}{ Isolate no. } & \multirow[b]{2}{*}{ CMW no. } & \multirow[b]{2}{*}{ Mycobank } & \multirow[b]{2}{*}{ Country } & \multirow[b]{2}{*}{ Host } & \multicolumn{5}{|c|}{ GenBank accession numbers } \\
\hline & & & & & & ITS & tef1- $\alpha$ & tub2 & $c m d A$ & $r p b 2$ \\
\hline \multirow[t]{3}{*}{ L. brasiliense } & CMM 4015* & & MB807525 & Brazil & $\begin{array}{l}\text { Mangifera } \\
\text { indica }\end{array}$ & JX464063 & JX464049 & & & \\
\hline & CMM 2320 & & & Brazil & Carica papaya & KC484814 & KC481544 & & & \\
\hline & & CMW 35884 & & Madagascar & $\begin{array}{l}\text { Adansonia } \\
\text { madagascariens } \\
\text { is }\end{array}$ & KU887094 & KU886972 & KU887466 & KU886755 & KU696345 \\
\hline \multirow[t]{2}{*}{ L. citricola } & CBS $124707 *$ & CMW 37046 & MB16777 & Iran & Citrus sp. & GU945354 & GU945340 & KU887505 & KU886760 & KU696351 \\
\hline & CBS 124706 & CMW 37047 & & Iran & Citrus sp. & GU945353 & GU945339 & KU887504 & KU886759 & KU696350 \\
\hline \multirow[t]{2}{*}{ L. crassispora } & CBS $118741^{*}$ & CMW 14691 & MB500235 & Australia & Santalum album & DQ103550 & DQ103557 & KU887506 & KU886761 & KU696353 \\
\hline & & CMW 13488 & & Venezuela & $\begin{array}{l}\text { Eucalyptus } \\
\text { urophylla }\end{array}$ & DQ103552 & DQ103559 & KU887507 & KU886762 & KU696352 \\
\hline \multirow[t]{4}{*}{ L. euphorbiicola } & CMM 3609* & & MB804872 & Brazil & Jatropha curcas & KF234543 & KF226689 & KF254926 & & \\
\hline & CMM 3651 & & & Brazil & J. curcas & KF234553 & KF226711 & KF254937 & & \\
\hline & & CMW 33350 & & Botswana & A. digitata & KU887149 & KU887026 & KU887455 & KU886754 & KU696346 \\
\hline & & CMW 36231 & & Zimbabwe & A. digitata & KU887187 & KU887063 & KU887494 & KU886756 & KU696347 \\
\hline \multirow[t]{2}{*}{ L. exigua } & CBS $137785^{*}$ & CMW 43391 & MB808355 & Tunisia & Retama raetam & KJ638317 & KJ638336 & KU887509 & KU886764 & KU696355 \\
\hline & PD 161 & & & USA & Pistachia vera & GU251122 & GU251254 & & & \\
\hline \multirow[t]{2}{*}{ (L. americana) } & CERC 1961* & & MB810934 & USA & P. vera & KP217059 & KP217067 & KP217075 & & \\
\hline & CERC 1960 & & & USA & P. vera & KP217058 & KP217066 & KP217074 & & \\
\hline \multirow[t]{2}{*}{ L. gonubiensis } & CBS $115812 *$ & CMW 14077 & MB500079 & South Africa & $\begin{array}{l}\text { Syzigium } \\
\text { cordatum }\end{array}$ & DQ458892 & DQ458877 & DQ458860 & KU886768 & KU696359 \\
\hline & CBS 116355 & CMW 14078 & & South Africa & S. cordatum & AY639594 & DQ103567 & EU673126 & KU886767 & KU696358 \\
\hline \multirow{2}{*}{$\begin{array}{l}\text { L. } \\
\text { hormozganensis }\end{array}$} & CBS $124709 *$ & CMW 37050 & MB16779 & Iran & Olea sp. & GU945355 & GU945343 & KU887515 & KU886770 & KU696361 \\
\hline & CBS 124708 & CMW 40931 & & Iran & M. indica & GU945356 & GU945344 & KU887514 & KU886769 & KU696360 \\
\hline L. indica & IBP 01 & & MB810909 & India & wood & $\begin{array}{l}\text { KM37615 } \\
1\end{array}$ & & & & \\
\hline
\end{tabular}




\begin{tabular}{|c|c|c|c|c|c|c|c|c|c|c|}
\hline \multirow[b]{2}{*}{ Species } & \multirow[b]{2}{*}{ Isolate no. } & \multirow[b]{2}{*}{ CMW no. } & \multirow[b]{2}{*}{ Mycobank } & \multirow[b]{2}{*}{ Country } & \multirow[b]{2}{*}{ Host } & \multicolumn{5}{|c|}{ Genbank accession numbers } \\
\hline & & & & & & ITS & tef1- $\alpha$ & tub2 & cmdA & $r p b 2$ \\
\hline \multirow[t]{2}{*}{ L. iraniensis } & CBS 124710* & CMW 37051 & MB16780 & Iran & $\begin{array}{l}\text { Salvadora } \\
\text { persica }\end{array}$ & GU945348 & GU945336 & KU887516 & KU886771 & KU696363 \\
\hline & CBS 124711 & CMW 37052 & & Iran & Juglans sp. & GU945347 & GU945335 & KU887517 & KU886772 & KU696362 \\
\hline \multirow[t]{3}{*}{ (L. jatrophicola) } & CMM $3610^{*}$ & & MB804869 & Brazil & J. curcas & KF234544 & KF226690 & KF254927 & & \\
\hline & & CMW 36237 & & Mozambique & A. digitata & KU887121 & KU886998 & KU887499 & KU886757 & KU696348 \\
\hline & & CMW 36239 & & Mozambique & A. digitata & KU887123 & KU887000 & KU887501 & KU886758 & KU696349 \\
\hline L. laeliocattleyae & CBS 130992* & CMW 40930 & MB564516 & Egypt & M. indica & JN814397 & JN814424 & KU887508 & KU886763 & KU696354 \\
\hline (L. egyptiacae) & BOT-29 & & & Egypt & M. indica & JN814401 & JN814428 & & & \\
\hline \multirow[t]{2}{*}{ L. lignicola } & CBS $134112 *$ & CMW 40932 & MB801317 & Thailand & dead wood & JX646797 & KU887003 & JX646845 & & KU696364 \\
\hline & \multicolumn{2}{|l|}{ MFLUCC 11-0656 } & MB805462 & Thailand & dead wood & JX646798 & & JX646846 & & \\
\hline L. macrospora & CMM $3833^{*}$ & & MB804871 & Brazil & J. curcas & KF234557 & KF226718 & KF254941 & & \\
\hline \multirow[t]{2}{*}{ L. mahajangana } & CBS $124925^{*}$ & CMW 27801 & MB514012 & Madagascar & $\begin{array}{l}\text { Terminalia } \\
\text { catappa }\end{array}$ & FJ900595 & FJ900641 & KU887518 & KU886773 & KU696365 \\
\hline & CBS 124926 & CMW 27818 & & Madagascar & T. catappa & FJ900596 & FJ900642 & KU887519 & KU886774 & KU696366 \\
\hline L. margaritacea & CBS 122519* & CMW 26162 & MB512052 & Australia & A. gregorii & EU144050 & EU144065 & KU887520 & KU886775 & KU696367 \\
\hline \multirow[t]{2}{*}{ L. mediterranea } & CBS $137783^{*}$ & CMW 43392 & MB808356 & Italy & Quercus ilex & KJ638312 & KJ638331 & KU887521 & KU886776 & KU696368 \\
\hline & CBS 137784 & CMW 43393 & & Italy & Vitis vinifera & KJ638311 & KJ638330 & KU887522 & KU886777 & KU696369 \\
\hline \multirow[t]{2}{*}{ L. missouriana } & CBS128311* & CMW 40933 & MB519954 & USA & Catawba & HQ288225 & HQ288267 & HQ288304 & KU886778 & KU696370 \\
\hline & CBS 128312 & CMW 40934 & & USA & Catawba & HQ288226 & HQ288268 & HQ288305 & KU886779 & KU696371 \\
\hline \multirow[t]{2}{*}{ L. parva } & CBS 456.78* & CMW 40935 & MB510942 & Colombia & $\begin{array}{l}\text { cassava field } \\
\text { soil }\end{array}$ & EF622083 & EF622063 & KU887523 & KU886780 & KU696372 \\
\hline & CBS 494.78 & CMW 40936 & & Colombia & $\begin{array}{l}\text { cassava field } \\
\text { soil }\end{array}$ & EF622084 & EF622064 & EU673114 & KU886781 & KU696373 \\
\hline \multirow[t]{2}{*}{ L. plurivora } & CBS $120832 *$ & CMW 40937 & MB501322 & South Africa & Prunus salicina & EF445362 & EF445395 & KU887524 & KU886782 & KU696374 \\
\hline & CBS 121103 & CMW 40938 & & South Africa & $V$. vinifera & AY343482 & EF445396 & KU887525 & KU886783 & KU696375 \\
\hline \multirow[t]{2}{*}{$\begin{array}{l}\text { L. } \\
\text { pseudotheobromae }\end{array}$} & CBS $116459 *$ & CMW 40939 & MB510941 & Costa Rica & $\begin{array}{l}\text { Gmelina } \\
\text { arborea }\end{array}$ & EF622077 & EF622057 & EU673111 & KU886784 & KU696376 \\
\hline & & CMW 9074 & & Mexico & Pinus sp. & AY236952 & AY236901 & KU887526 & KU886785 & KU696377 \\
\hline \multirow[t]{2}{*}{ L. pyriformis } & CBS $121770 *$ & CMW 25414 & MB518722 & Namibia & Acacia mellifera & EU101307 & EU101352 & KU887527 & KU886786 & KU696378 \\
\hline & CBS 121771 & CMW 25415 & & Namibia & A. mellifera & EU101308 & EU101353 & KU887528 & KU886787 & KU696379 \\
\hline
\end{tabular}




\begin{tabular}{|c|c|c|c|c|c|c|c|c|c|c|}
\hline \multirow[b]{2}{*}{ Species } & \multirow[b]{2}{*}{ Isolate no. } & \multirow[b]{2}{*}{ CMW no. } & \multirow[b]{2}{*}{ Mycobank } & \multirow[b]{2}{*}{ Country } & \multirow[b]{2}{*}{ Host } & \multicolumn{5}{|c|}{ Genbank accession numbers } \\
\hline & & & & & & ITS & tef1- $\alpha$ & tub2 & $c m d A$ & $r p b 2$ \\
\hline \multirow{2}{*}{ L. rubropurpurea } & CBS $118740 *$ & CMW 14700 & MB500236 & Australia & E. grandis & DQ103553 & DQ103571 & EU673136 & KU886788 & KU696380 \\
\hline & WAC 12536 & CMW 15207 & & Australia & E. grandis & DQ103554 & DQ103572 & KU887530 & & KU696381 \\
\hline \multirow[t]{2}{*}{ L. subglobosa } & CMM $3872 *$ & & MB804870 & Brazil & J. curcas & KF234558 & KF226721 & KF254942 & & \\
\hline & CMM 4046 & & & Brazil & J. curcas & KF234560 & KF226723 & KF254944 & & \\
\hline \multirow[t]{2}{*}{ L. thailandica } & CBS 138760 & & MB810169 & Thailand & M. indica & KP217058 & KP217066 & & & \\
\hline & CBS 138653 & & & Thailand & $\begin{array}{l}\text { Phyllanthus } \\
\text { acidus }\end{array}$ & KJ193637 & KJ193681 & & & \\
\hline \multirow[t]{2}{*}{ L. theobromae } & CBS $164.96^{*}$ & CMW 40942 & MB188476 & New Guinea & $\begin{array}{l}\text { Fruit on coral } \\
\text { reef coast }\end{array}$ & AY640255 & AY640258 & KU887532 & KU886789 & KU696383 \\
\hline & CBS 111530 & CMW 40953 & & Unknown & Unknown & EF622074 & EF622054 & KU887531 & KU886790 & KU696382 \\
\hline \multirow[t]{2}{*}{ L. venezuelensis } & CBS $118739^{*}$ & CMW 13511 & MB500237 & Venezuela & A. mangium & DQ103547 & DQ103568 & KU887533 & KU886791 & KU696384 \\
\hline & WAC 12540 & CMW 13512 & & Venezuela & A. mangium & DQ103548 & DQ103569 & KU887534 & KU886792 & \\
\hline \multirow[t]{2}{*}{ L. viticola } & CBS $128313^{*}$ & CMW 40944 & MB519955 & USA & $\begin{array}{l}\text { hybrid grape } \\
\text { Vignoles }\end{array}$ & HQ288227 & HQ288269 & HQ288306 & KU886793 & KU696385 \\
\hline & CBS 128314 & CMW 41372 & & USA & Chardonel & HQ288228 & HQ288270 & HQ288307 & KU886794 & KU696386 \\
\hline $\begin{array}{l}\text { Botryosphearia } \\
\text { dothidea }\end{array}$ & CBS 115476 & CMW 8000 & & Switzerland & Prunus sp. & KF766151 & AY236898 & & & DQ677944 \\
\hline
\end{tabular}

BOT: A. M. Ismail, Plant Pathology Research Institute, Egypt.

CERC: Culture collection of China Eucalypt Research Centre, Chinese Academy of Forestry, ZhanJiang, GuangDong, China.

CMM: Culture Collection of Phytopathogenic Fungi "Prof. Maria Menezes", Universidade Federal Rural de Pernambuco, Recife, Brazil.

CMW: Culture collection of the Forestry and Agricultural Biotechnology Institute (FABI), University of Pretoria, Pretoria, South Africa.

CBS: Centraalbureau voor Schimmelcultures, Utrecht, The Netherlands; Canada.

MFLUCC: Mae Fah Luang University Culture Collection, ChiangRai, Thailand.

WAC: Department of Agriculture Western Australia Plant Pathogen Collection, South Perth, Western Australia

* Ex-type strain. 
included. These were L. americana from the United States of America, which has subsequently been reduced to synonymy with L. exigua (Rodríguez-Gálvez et al. 2016) and L. thailandica (Trakunyingcharoen et al. 2015) from Thailand. The ex-type isolate of $L$. laeliocattleyae was not included in this study, however the ex-type isolate of L. egyptiacae, which was recently reduced to synonymy with L. laeliocattleyae (Rodríguez-Gálvez et al. 2016), was included.

All isolates, including those from baobabs, were grown for 7 days at $25{ }^{\circ} \mathrm{C}$ on $2 \%$ MEA, after which mycelium was scraped from the surfaces of the medium and freeze dried. Freeze dried mycelium was ground to a powder and DNA was extracted as described by Möller et al. (1992). DNA was amplified with PCR using commonly applied primers (Table 3).

Table 3 Primers used to amplify selected gene regions

\begin{tabular}{lll}
\hline Primer name & Sequence & Reference \\
\hline ITS1-F & 5'-CTTGGTCATTTAGAGGAAGTAA-3' & Gardes and Bruns 1993 \\
ITS4 & 5'-TCCTCCGCTTATTGATATGC-3' & White et al.1990 \\
EF1- 688F & 5'-CGGTCACTTGATCTACAAGTGC-3' & Alves et al. 2008 \\
EF1- 1251R & 5'-CCTCGAACTCACCAGTACCG-3' & Alves et al. 2008 \\
Bt2a & 5'-GGTAACCAAATCGGTGCTGCTTTC-3' & Glass and Donaldson 1995 \\
Bt2b & 5'-ACCCTCAGTGTAGTGACCCTTGGC-3' & Glass and Donaldson 1995 \\
rpb2-LasF & 5'-GGTAGCGACGTCACTCCT-3' & This study \\
rpb2-LasR & 5'-GCGCAAATACCCAGAATCAT-3' & This study \\
CAL-228F & 5'-GAGTTCAAGGAGGCCTTCTCCC-3' & Carbone and Kohn 1999 \\
CAL-737R & 5'-CATCTTTCTGGCCATCATGG-3' & Carbone and Kohn 1999 \\
\hline
\end{tabular}

The ITS and tef1- $\alpha$ gene regions were amplified for all Lasiodiplodia isolates from baobab trees. A sub-set of isolates from different geographic areas with different ITS and tef1- $\alpha$ sequences were further characterised by amplifying and sequencing the $\beta$-tubulin 2 (tub2) and RNA polymerase subunit II ( $r p b 2)$ gene regions. The $t u b 2$, calmodulin ( $c m d A)$ and $r p b 2$ gene regions were also sequenced for all available isolates of previously described species. New primers (Table 3) were developed for the $r p b 2$ region, because the primers normally used for the Botryosphaeriaceae were not effective for Lasiodiplodia. The new forward primer binds 
at the same position as the primer developed by Sakalidis et al. (2011b) with one base pair that was changed. The reverse primer binds four base pairs away from the primer developed by Sakalidis et al. (2011b).

All amplification reactions consisted of 1.5 U MyTaq ${ }^{\mathrm{TM}}$ DNA Polymerase (Bioline, London, UK), $5 \mu \mathrm{L}$ MyTaq PCR reaction buffer and $0.2 \mu \mathrm{M}$ of each primer, $50 \mathrm{ng}$ template DNA (made up to a total volume of $25 \mu \mathrm{L}$ with PCR grade water). PCR conditions were $2 \mathrm{~min}$ at $95{ }^{\circ} \mathrm{C}$, followed by 35 cycles of $30 \mathrm{~s}$ at $94{ }^{\circ} \mathrm{C}, 30 \mathrm{~s}$ at $52-54{ }^{\circ} \mathrm{C}$ (depending on gene region), 1 min at $72{ }^{\circ} \mathrm{C}$, and a last extension step of $8 \mathrm{~min}$ at $72{ }^{\circ} \mathrm{C}$. PCR products were visualised on a $1 \%$ agarose gel stained with GelRed (Biotium, Hayward, California, USA) and successful PCR products were purified with Exosap (Mixture of Exonuclease I and FastAP Alkaline Phosphatase) (Thermo Fisher Scientific Inc. Waltham, MA, USA) following the manufacturer's specifications.

DNA sequencing was conducted with the ABI Prism ${ }^{\circledR}$ Big Dye ${ }^{\mathrm{TM}}$ Terminator 3.1 Ready Reaction Cycle sequencing Kit (Applied Biosystems, Foster City, CA, USA). Sequences were determined with an ABI PRISMTM 3100 Genetic Analyzer (Applied Biosystems) at the University of Pretoria. The same primer sets as those used for PCR amplification were utilised. Forward and reverse sequences were assembled with CLC Main workbench v.6.1 (CLC Bio, www.clcbio.com).

\subsection{Phylogenetic analyses}

Sequences of the type strains of all Lasiodiplodia species on GenBank (http://www.ncbi.nlm.nih.gov) were downloaded and aligned with newly generated sequences using the MAFFT v.7 server (http://mafft.cbrc.jp/alignment/server/) and manually adjusted where necessary. Botryosphaeria dothidea was used as the outgroup taxon in all analyses other than for $c m d A$, which was midpoint rooted. This exception was necessary because there were no closely related sequences for $c m d A$ available on GenBank. Individual trees of existing species were first generated and the best substitution models were determined for each dataset with jModeltest v.2.1.3 using the Akaike Information Criterion (AIC) (Darriba et al. 2012; Guindon and Gascuel 2003). Maximum Likelihood (ML) analyses were done with PhyML v.3.0 (Guindon and Gascuel 2003) and 1000 bootstrap replicates were run to determine confidence levels for the branches. PHYLIP v.3.6. (Felsenstein 2005) was used to generate consensus trees using the consense option. Maximum parsimony (MP) analyses were performed using PAUP v.4.0 beta 10 (Swofford 2003) with Tree Bisection- 
Reconnection (TBR), with 10 trees saved per replicate and with 1000 bootstrap replicates. Bayesian inference, based on a Markov Chain Monte Carlo (MCMC) approach, was performed in MrBayes v.3.1.2 (Ronquist and Huelsenbeck 2003), with 1000000 generations, sampled every 100 generations. Burnin values were determined using Microsoft Excel 2013. All sampled trees having lower values than the burn-in were discarded.

Re-evaluation of existing Lasiodiplodia species identified hybrid isolates and species. These were not included in further analyses. A combined dataset of tub2, ITS, tef1- $\alpha$ and $r p b 2$ was generated to identify the species from baobabs. The same analyses were applied as described above to generate phylogenetic trees.

\subsection{Pathogenicity trials}

Baobab seeds (A. digitata s.l.) were treated with hot water overnight and placed in germination trays with a mixture of sand, top soil and potting soil. After germination, the seedlings were transplanted into larger containers in a mixture of sand : top soil : potting soil (50:25:25). Trees were grown in containers for three years.

Lasiodiplodia isolates of different species and from different regions were selected to test whether any of the species are pathogenic to baobab trees. Variability in virulence between isolates of the species that were most commonly isolated from baobab trees was also tested. A total of 13 Lasiodiplodia isolates including L. euphorbiicola (3 isolates), L. iraniensis (1 isolate), L. jatrophicola (1 isolate), L. mahajangana (6 isolates) and L. pseudotheobromae (2 isolates) were selected from amongst isolates from baobabs in southern Africa for use in pathogenicity trials. Isolates were grown on 2\% MEA for 7 days. A $5 \mathrm{~mm}$-diameter cork borer was used to cut holes approximately $5 \mathrm{~mm}$ deep in the stems of the trees about $10 \mathrm{~cm}$ above ground level. Using the same size cork borer, discs of agar covered in mycelium were cut from actively growing cultures (one-week-old) and these were placed in the wounds on the plant stems. The inoculation sites were sealed with parafilm to minimize desiccation and to reduce chances of contamination. A randomised block design was generated with www.randomization.com and 10 replicates per treatment were used. Non-colonised 2\% MEA was used for the controls. The trial was left for six weeks after which the lesions were measured and fungi re-isolated. Statistical significance of the data was determined with a single factor ANOVA followed by a Duncan multiple range test in Microsoft Excel 2010. 


\section{Results}

\subsection{Sample collection and isolation}

Endophyte isolations yielded a total of 420 isolates that resembled Lasiodiplodia species based on culture morphology. A total of 130 isolates were obtained from South Africa, 26 from Botswana, 30 from Namibia, 5 from Zimbabwe, 7 from Mozambique and 104 from Madagascar. From West Africa 59 isolates were obtained from Cameroon, 30 from Senegal and 29 from Benin. Of these, 320 were selected for further identification by DNA sequencing, after excluding multiple isolates from the same trees. The isolations from tissue samples that had been surface disinfested with $\mathrm{H}_{2} \mathrm{O}_{2}$ yielded more than double the number of Lasiodiplodia cultures than those where $\mathrm{HOCl}$ and $\mathrm{EtOH}$ were used. This may account for the low numbers of isolates obtained from Namibia and Botswana and from the first sampling trip in South Africa (20 isolates).

\subsection{Phylogenetic analyses}

Alignment of sequences for previously described species yielded data sets of $461 \mathrm{bp}, 517 \mathrm{bp}$, 423 bp, 532 bp and 510 bp for the ITS, tef1- $\alpha$, tub2, rpb2 and $c m d A$, respectively. The alignment of the tef1- $\alpha$ sequences was the most problematic, due to a large amount of variability within the intron 3 region, and minor manual adjustments were made where necessary. The tef1- $\alpha$ sequence for L. lignicola on GenBank (JX646862) did not group within Lasiodiplodia and is deemed to be an incorrect sequence for this isolate. A new tef1- $\alpha$ sequence (KU887003) was generated from the ex-type strain and used in analyses.

Phylogenetic analyses of sequences from the ITS (Fig 2a) and tub2 (Fig 2b) loci did not differentiate between all Lasiodiplodia species. Analyses of $r p b 2$ sequences (Fig 2c) could distinguish between most Lasiodiplodia species other than L. parva and L. euphorbiicola, and L. brasiliense, L. laeliocattleyae, L. theobromae, as well as L. mediterranea, L. missouriana and L. viticola. The most variable locus was tef1- $\alpha$ (Fig $2 \mathrm{~d}$ ) which could distinguish between most species, but not between L. brasiliense and L. viticola or between L. iraniensis and $L$. jatrophicola. The $c m d A$ (Fig 2e) dataset appeared to distinguish between species better than ITS and $t u b 2$. None of the loci tested could distinguish between all of the currently described species and a combination of loci was, therefore, needed to identify Lasiodiplodia to species level. 

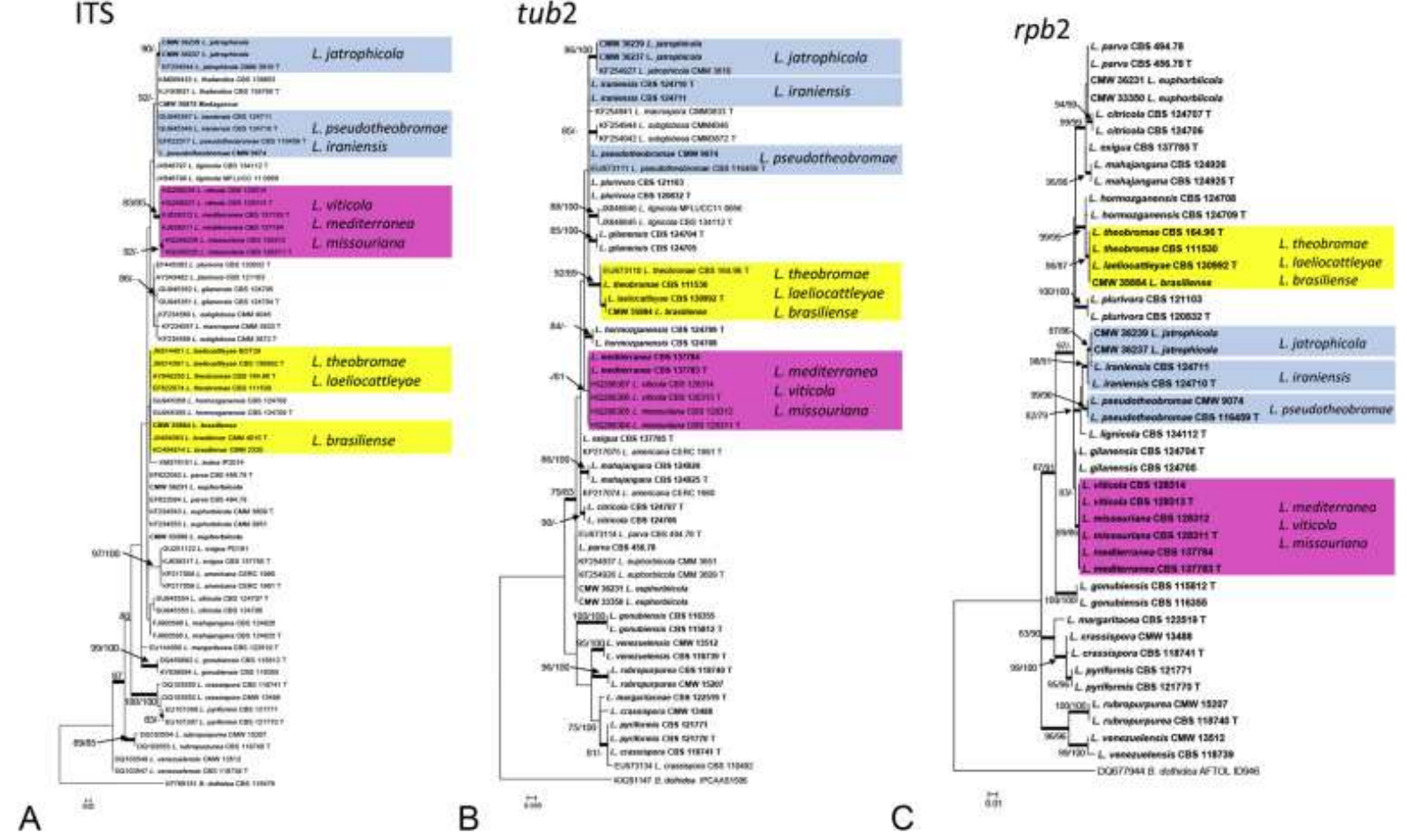

$$
\text { tef1- } \alpha
$$

cmdA
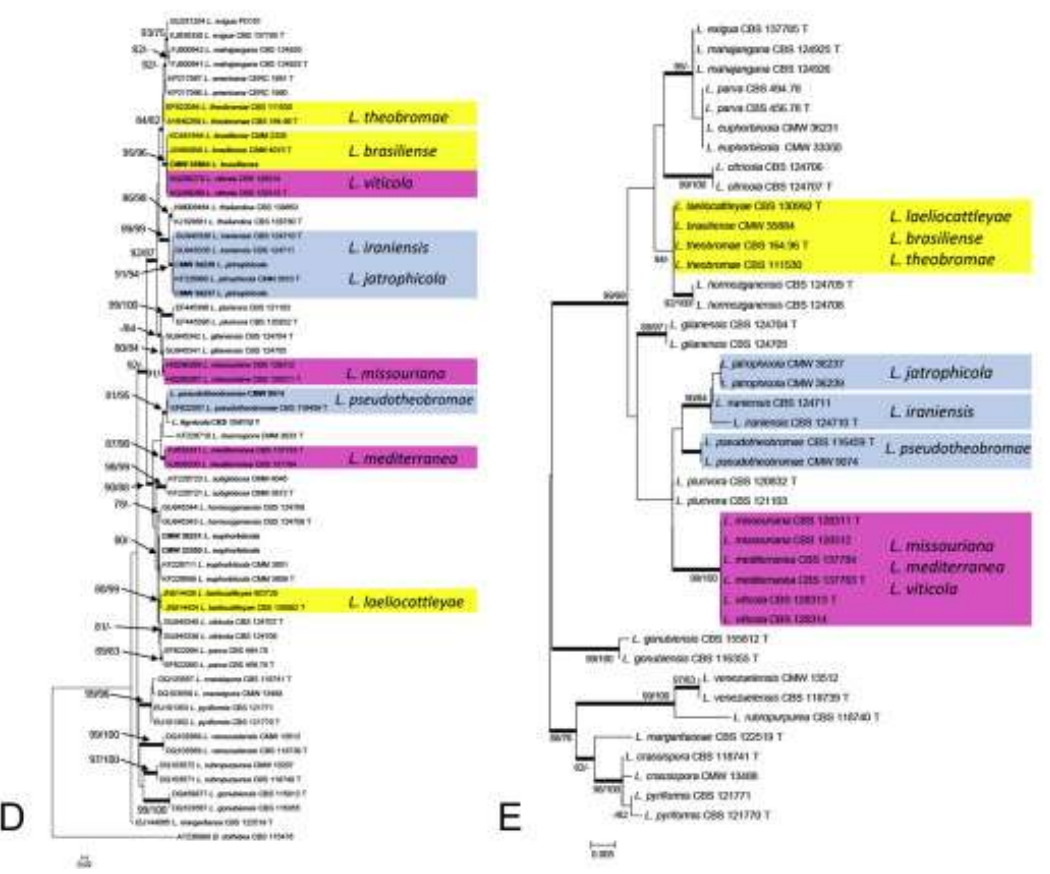

Fig 2 Maximum likelihood trees of currently described Lasiodiplodia species based on partial (a) ITS, (b) tub2, (c) $r p b 2$, (d) $t e f 1-\alpha$ and (e) $c m d A$ gene sequences. Sequences in bold, as well as all $c m d A$ sequences, were obtained during this study. Bootstrap values above 70\% (indicated as ML/MP) are given at the nodes. Branches with Bayesian posterior probabilities of more than 0.95 are printed in bold. Trees a-d were rooted with $B$. dothidea and e was midpoint rooted. 
The trees from individual loci (Fig 2) for previously described species showed concordance between $t u b 2, c m d A$, ITS and $r p b 2$. In the tef1- $\alpha$ tree, some species failed to show the same groupings found in the other phylogenetic trees and were not considered congruent. These included the L. theobromae group (including L. brasiliense and L. laeliocattleyae), $L$. pseudotheobromae group (including L. iraniensis and L. jatrophicola) and the $L$. mediterranea group (including L. missouriana and L. viticola). The incongruence of the species in the tef1- $\alpha$ tree could be explained only by accepting that some of these species, as represented by the ex-type isolates, were hybrids.

Based on the ITS dataset, L. theobromae was identical to L. laeliocattleyae, L. brasiliense and L. hormozganensis; tub2, cmdA and rpb2 also grouped $L$. theobromae and $L$. laeliocattleyae together. An ex-type isolate of L. brasiliense was not available to generate $t u b 2, c m d A$ and $r p b 2$ sequences, but an isolate (CMW 35884) from baobab grouped with the ex-type isolate of this species based on ITS and tef $1-\alpha$, and this isolate showed similarity to $L$. theobromae on tub2, cmdA and rpb2. Lasiodiplodia hormozganensis was a sister species to $L$. theobromae based on tub2, $c m d A$ and $r p b 2$, but not based on tef1- $\alpha$.

Lasiodiplodia pseudotheobromae grouped with L. iraniensis based on ITS and tub2, while rpb2 and cmdA separated L. pseudotheobromae from L. iraniensis, but still grouped them as sister species. While tef1- $\alpha$ also separated L. pseudotheobromae from L. iraniensis, it did not group them as sister species. The tef1- $\alpha$ locus also did not distinguish $L$. jatrophicola from $L$. iraniensis, as occurs with the ITS, tub2, $c m d A$ and $r p b 2$ sequences. Although an ex-type isolate of L. jatrophicola was not available for $r p b 2$ and $c m d A$ sequencing, several isolates from baobab trees (CMW 36237, CMW 36239) grouped with the ex-type isolate of this species based on its tefl- $\alpha$ and ITS sequences.

Lasiodiplodia iraniensis showed some variability within the species based on $r p b 2$ and $c m d A$ sequences. The ex-type isolate of L. iraniensis (CBS 124710) consistently grouped separate from $L$. jatrophicola based on ITS, $t u b 2, c m d A$ and $r p b 2$. However, the paratype isolate (CBS 124711) grouped with the ex-type isolate in ITS, but grouped between L. iraniensis and $L$. jatrophicola based on $c m d A$, and was identical to L. jatrophicola based on rpb2. This may indicate gene flow and supports the synonymy of L. jatrophicola with L. iraniensis based on a phylogeny of combined ITS and tef1- $\alpha$ data by Rodríguez-Gálvez et al. (2016).

When considering the $t u b 2, r p b 2$ and $c m d A$ sequences L. missouriana, L. mediterranea and L. viticola were identical. Although ITS separated the three species, it grouped them in a 
single clade. The tef1- $\alpha$ locus grouped the three species close to three other unrelated species and not as sister species, as would be expected based on the $t u b 2, r p b 2, c m d A$ and ITS loci.

The trees from the individual loci in conjunction with a decision tree (Fig 3) were used to determine which of the currently described species are hybrids, and this approach was also taken for the isolates from baobab trees. To give one example, isolate CMW 33342 grouped with L. mahajangana based on ITS and tef1- $\alpha$ and with L. euphorbiicola based on tub2 and $r p b 2$. This would place it in the category of multiple incongruent genes that grouped it with non-sister species and it is, therefore, identified as a hybrid.

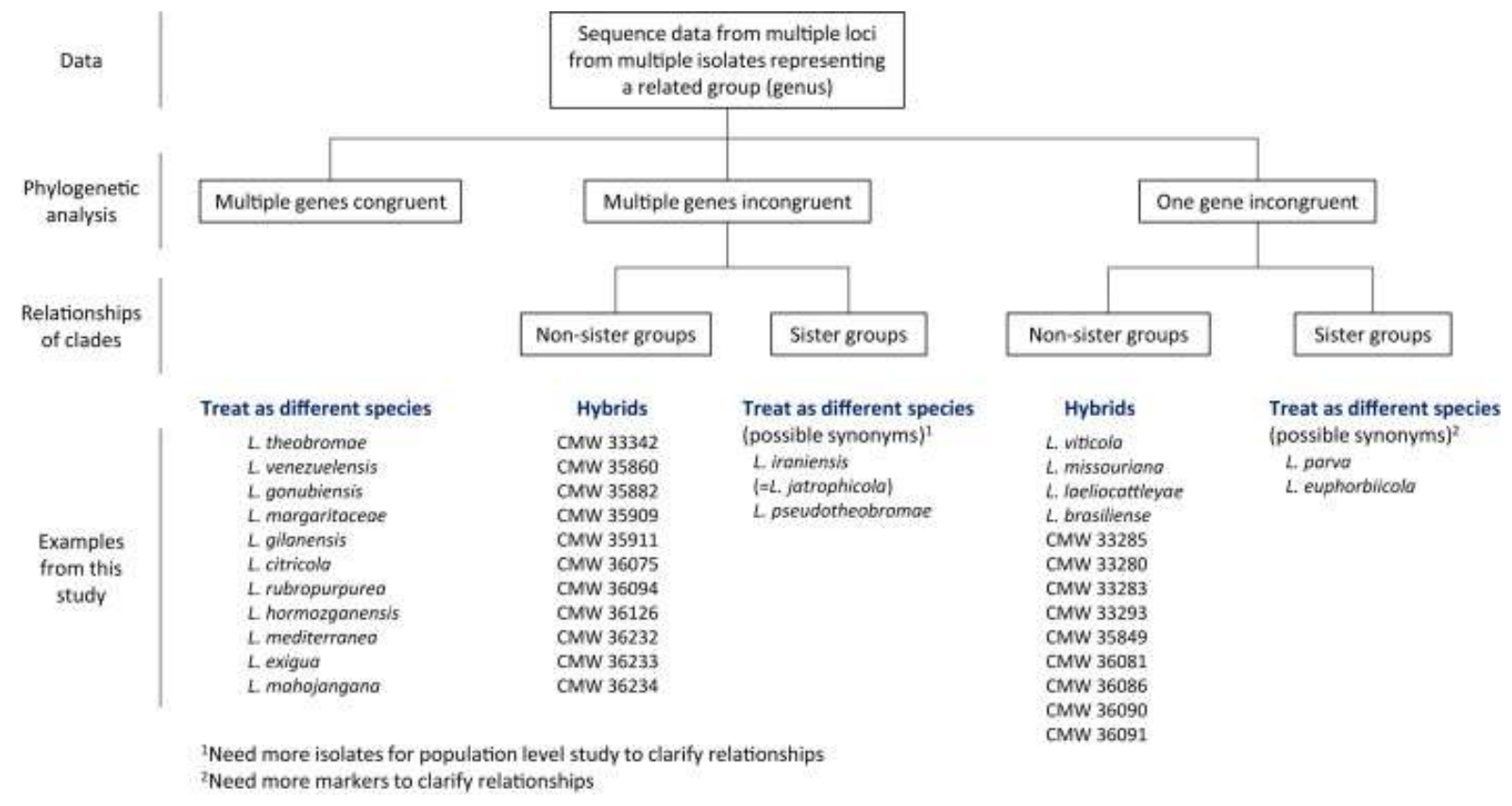

Fig 3 Decision tree used together with multiple single gene phylogenies to identify hybrids amongst Lasiodiplodia isolates. Species and isolates used as examples correlate to Fig. 2 and Table 4.

The ex-type strains of L. brasiliense, L. laeliocattleyae, L. missouriana and L. viticola displayed incongruence between all other loci and tef1- $\alpha$, grouping with distant species in the phylogenies of different loci. Following the logic provided by the decision tree in Fig 3, these isolates were considered hybrids. The species names are consequently invalid and they are designated here as hybrid species. All isolates identified as L. brasiliense, L. laeliocattleyae, L. missouriana and L. viticola were identified based on tef1- $\alpha$, which is where the incongruence with other genes emerge and as such they must also be hybrids. Isolates from baobab trees that appeared to be hybrids are not described as hybrid species because they could be transient hybrid isolates that may yet disappear. 


\subsection{Taxonomy}

Based on comparison of ITS, tef1- $\alpha, t u b 2, r p b 2$ and $c m d A$ gene regions for the ex-type isolates, L. laeliocattleyae, L. brasiliense, L. missouriana and L. viticola are designated as hybrid species and are described as follows:

Lasiodiplodia $\times$ laeliocattleyae A.M. Ismail, L. Lombard \& Crous nothosp., Australas. Plant Path. 41: 655. 2012. MycoBank MB564516.

Lasiodiplodia laeliocattleyae was described from the Laeliocattleya orchid in Italy (Rodríguez-Gálvez et al. 2016) and has also been reported from Mangifera indica (Mango) in Egypt, Jatropha curcas in Brazil (Machado et al. 2014) and Adansonia grandidieri in Madagascar (this study). This species has conidial sizes that overlap with those of $L$. theobromae, although the conidia of L. laeliocattleyae are slightly smaller than those reported for L. theobromae. DNA sequences of L. theobromae and L. laeliocattleyae are identical based on ITS, $r p b 2$ and $c m d A$ and there is a one base pair difference in the $t u b 2$ gene between L. theobromae and L. laeliocattleyae sequences. However, the tef1- $\alpha$ sequences of these two species group them as distantly related, non-sister groups. Therefore, L. laeliocattleyae is considered a hybrid of L. theobromae and another species, possibly L. parva or L. citricola.

Lasiodiplodia $\times$ brasiliense M.S.B. Netto, M.W. Marques \& A.J.L. Phillips nothosp., Fungal Divers 67: 134. 2014. MycoBank MB807525

Lasiodiplodia brasiliense was described from Carica papaya and M. indica in Brazil (Netto et al. 2014). It has also been reported from Tectona grandis in Thailand (Doilom et al. 2015), strawberries in Turkey (Yildiz et al. 2014) and A. madagascariensis in Madagascar (this study). The conidial sizes of $L$. theobromae and L. brasiliense overlap, although the conidia of $L$. brasiliense are slightly smaller than those reported for $L$. theobromae. Based on ITS, $r p b 2$ and $c m d A$ sequences $L$. theobromae and L. brasiliense are identical, while there is only one base pair difference between them in sequences of the tub2 locus. Based on the tef1- $\alpha$ dataset, $L$. brasiliense is identical to $L$. viticola and groups as a sister species to $L$. theobromae. The hybrid Lasiodiplodia $\times$ brasiliense described here could have arisen from hybridisation between $L$. theobromae and another currently unknown species. 


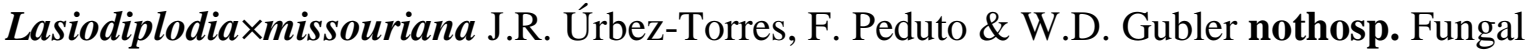
Divers 52: 181. 2012. MycoBank MB519954

Lasiodiplodia missouriana was described from grape cultivars in the USA (Urbez-Torres et al. 2012). In the current study L. missouriana grouped with L. mediterranea and the hybrid species L. viticola based on $t u b 2, c m d A$, ITS and $r p b 2$ sequences, but based on tef1- $\alpha$ it grouped with $L$. gilanensis with only one base pair difference. Therefore, isolates of the hybrid species L. ×missouriana described here appear to have arisen through a hybridisation between L. mediterranea and L. gilanensis.

Lasiodiplodia $\times$ viticola J.R. Úrbez-Torres, F. Peduto \& W.D. Gubler nothosp. Fungal Divers 52: 183. 2012. MycoBank MB519955

Lasiodiplodia viticola was described from grape cultivars (Urbez-Torres et al. 2012), and has also been found on M. indica in Brazil (Marques et al. 2013). Based on tub2, cmdA, ITS and $r p b 2$ sequences for the ex-type isolate the hybrid species L. $\times$ viticola, defined here, groups with L. mediterranea and hybrid species L. $\times$ missouriana. However, based on tef1- $\alpha$ it is identical to hybrid species L. $\times$ brasiliense that is closely related to L. theobromae, as discussed above. Isolates of Lasiodiplodia $\times$ viticola have probably arisen from hybridization between L. mediterranea and L. theobromae. Grape is a known host of L. theobromae (Úrbez-Torres and Gubler 2009) and also of L. mediterranea (Linaldeddu et al. 2015) and coinfection of this host by the two species may have provided the opportunity for the hybridization.

\subsection{Identification of isolates from baobab trees}

The individual trees for ITS, tef1- $\alpha, t u b 2$ and $r p b 2$ sequence datasets for the baobab isolates were compared and 30 hybrid isolates from baobabs excluded (Table 4). The individual trees, as well as a combined dataset for the tub2, ITS, tef1- $\alpha$ and $r p b 2$ sequences were then used to identify Lasiodiplodia species from baobab trees. The combined dataset contained 1772 base pairs, of which 1410 characters were constant and 217 characters were parsimonyinformative, while 145 variable characters were parsimony uninformative. Maximum Parsimony analyses yielded a tree (Fig 4) having a $\mathrm{RI}=0.92, \mathrm{CI}=0.76$ and $\mathrm{HI}=0.244$, and a tree length of 545. The best model selected for Maximum Likelihood analyses for the combined dataset was $\mathrm{TrN}+\mathrm{G}$. 
Table 4 Hybrid Lasiodiplodia isolates from baobab trees, indicating which species isolates grouped with based on different gene regions.

\begin{tabular}{|c|c|c|c|c|c|}
\hline Isolate & Country & ITS & tef1- $\alpha$ & $t u b 2$ & $r p b 2$ \\
\hline CMW 33258 & Senegal & $\mathrm{M}$ & $\mathrm{Eu}$ & $\mathrm{Eu}$ & $\mathrm{Eu}$ \\
\hline CMW 33280 & Benin & M & M & $\mathrm{Eu}$ & M \\
\hline CMW 33283 & Benin & M & $\mathrm{Eu}$ & $\mathrm{Eu}$ & $\mathrm{Eu}$ \\
\hline CMW 33293 & Benin & M & $\mathrm{Eu}$ & $\mathrm{Eu}$ & $\mathrm{Eu}$ \\
\hline CMW 33342 & SA & M & M & $\mathrm{Eu}$ & $\mathrm{Eu}$ \\
\hline CMW 35849 & Madagascar & M & M & $\mathrm{Eu}$ & $\mathrm{Eu}$ \\
\hline CMW 35860 & Madagascar & M & M & $\mathrm{Eu}$ & $\mathrm{Eu}$ \\
\hline CMW 35882 & Madagascar & M & M & $\mathrm{Eu}$ & $\mathrm{Eu}$ \\
\hline CMW 35909 & Madagascar & M & M & $\mathrm{Eu}$ & $\mathrm{Eu}$ \\
\hline CMW 35911 & Madagascar & M & M & $\mathrm{Eu}$ & $\mathrm{Eu}$ \\
\hline CMW 36075 & Cameroon & $\mathrm{PS} / \mathrm{I}$ & M & $\mathrm{Eu}$ & $\mathrm{M}$ \\
\hline CMW 36081 & Cameroon & PS/I & $\mathrm{Eu}$ & $\mathrm{Eu}$ & $\mathrm{Eu}$ \\
\hline CMW 36086 & Cameroon & $\mathrm{Eu}$ & I & PS/I & I \\
\hline CMW 36090 & Cameroon & M & M & $\mathrm{Eu}$ & M \\
\hline CMW 36091 & Cameroon & M & $\mathrm{Eu}$ & $\mathrm{Eu}$ & $\mathrm{Eu}$ \\
\hline CMW 36092 & Cameroon & M & EU & $\mathrm{Eu}$ & $\mathrm{Eu}$ \\
\hline CMW 36094 & Cameroon & $\mathrm{Eu}$ & M & M & EX \\
\hline CMW 36096 & Cameroon & $\mathrm{Eu}$ & M & $\mathrm{Eu}$ & $\mathrm{Eu}$ \\
\hline CMW 36099 & Cameroon & M & $\mathrm{Eu}$ & $\mathrm{Eu}$ & $\mathrm{Eu}$ \\
\hline CMW 36105 & Cameroon & $\mathrm{Eu}$ & M & $\mathrm{Eu}$ & $\mathrm{Eu}$ \\
\hline CMW 36106 & Cameroon & M & $\mathrm{Eu}$ & $\mathrm{Eu}$ & $\mathrm{Eu}$ \\
\hline CMW 36119 & Cameroon & EX & $\mathrm{Eu}$ & $\mathrm{Eu}$ & $\mathrm{Eu}$ \\
\hline CMW 36122 & Cameroon & M & $\mathrm{Eu}$ & $\mathrm{Eu}$ & $\mathrm{Eu}$ \\
\hline CMW 36123 & Cameroon & M & I & PS/I & I \\
\hline CMW 36126 & Cameroon & $\mathrm{Eu}$ & M & M & $\mathrm{Eu}$ \\
\hline CMW 36232 & Zimbabwe & $\mathrm{Eu}$ & M & M & $\mathrm{Eu}$ \\
\hline CMW 36233 & Zimbabwe & $\mathrm{Eu}$ & M & M & $\mathrm{Eu}$ \\
\hline CMW 36234 & Zimbabwe & $\mathrm{Eu}$ & M & M & $\mathrm{Eu}$ \\
\hline
\end{tabular}

$\mathrm{M}=$ Lasiodiplodia mahajangana, $\mathrm{Eu}=$ L. euphorbiicola, $\mathrm{Ex}=$ L. exigua, $\mathrm{I}=$ L. iraniensis, $\mathrm{PS} / \mathrm{I}=$ L. pseudotheobrome/L.iraniensis clade 


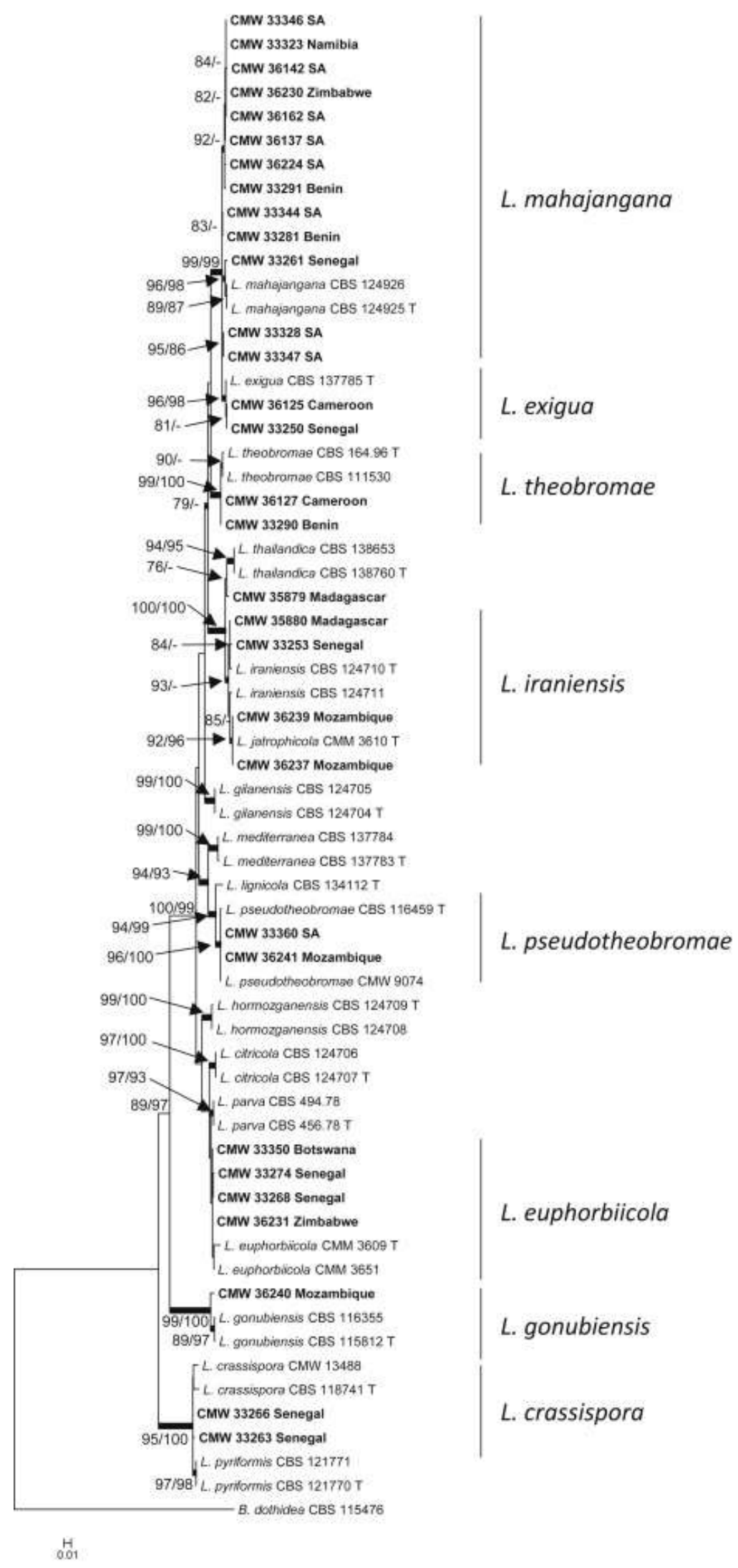

Fig 4 Maximum likelihood tree of currently described Lasiodiplodia species based on partial tub2, ITS, tef1- $\alpha$ and $r p b 2$ gene regions, tree was rooted with $B$. dothidea. Sequences in bold were obtained during this study. Bootstrap values above 70\% (indicated as ML/MP) are given at the nodes. Branches with Bayesian posterior probabilities of more than 0.95 are printed in bold 
The isolates from baobab trees were identified as L.×brasiliense, L. crassispora, L.×laeliocattleyae, L. euphorbiicola, L. exigua, L. gonubiensis, L. iraniensis, L. mahajangana, L. pseudotheobromae and L. theobromae. One isolate from Madagascar grouped close to, but distinct from L. thailandica and L. iraniensis. The L. mahajangana clade included the largest number of isolates (186) and it also had the largest degree of variation within a species, forming four sub-groups. Isolates in these sub-groups did not consistently group together based on different loci and could not be described as new species. This species was found in all countries sampled and appears to be the dominant species in South Africa, Namibia and Madagascar, where it was obtained from both healthy and diseased trees.

The second largest group of isolates (70) grouped with L. euphorbiicola. There was less sequence variation between these isolates than within the L. mahajangana group, but the same trend was evident where the sub-groups of isolates did not consistently group together based on the different gene regions. Lasiodiplodia euphorbiicola was the dominant species isolated from all three West African countries, where it occurred on both healthy and diseased trees. Other countries where it was found included Botswana, Namibia, Madagascar and Zimbabwe.

Species isolated only from West Africa included L. exigua (7 isolates) from Benin, Cameroon and Senegal and the two L. theobromae isolates that originated from Benin and Cameroon. Lasiodiplodia crassispora was isolated only from Senegal, and was collected from five trees. There was no distinction in the species assemblage from healthy and diseased trees.

Mozambique was the only country where L. gonubiensis were found, bringing the total number of species from that country to four. These were from only seven isolates obtained from six trees. Two isolates of L. pseudotheobromae were collected from South Africa and Mozambique respectively.

Lasiodiplodia iraniensis was isolated from healthy and diseased trees in Benin, Cameroon, Senegal, South Africa, Madagascar and Mozambique. There was some sequence variation between the different isolates. A single isolate from Madagascar (CMW 35879) grouped closest to L. thailandica, but distinct from both L. iraniensis and L. thailandica A group of 30 isolates (Table 4), mostly from Cameroon, grouped incongruently between trees from the various loci and these isolates are, therefore, considered as hybrids. Most of the 
hybrids formed between L. mahajangana and L. euphorbiicola, while two isolates were hybrids with L. exigua and L. euphorbiicola. Four isolates from Cameroon formed hybrids between L. iraniensis and L. euphorbiicola and / or L. mahajangana. There was one hybrid each from Senegal and South Africa, three from Benin and Zimbabwe each, and five from Madagascar. While there was only one isolate of L. euphorbiicola from Madagascar, all five of the hybrids from Madagascar were between L. mahajangana and L. euphorbiicola. This suggests that L. euphorbiicola is more prevalent in Madagascar than is apparent from this survey.

\subsection{Pathogenicity trials}

Sunken areas around the points of inoculation were observed on young baobab trees approximately three weeks after inoculation with the selected Lasiodiplodia species (Fig 5a). Some isolates sporulated profusely on the bark (Fig 5b) and parafilm, covering the inoculation sites. After six weeks, the lesions under the bark were measured (Fig 5c,d), but some lesions at the centres of the stems extended further up and down within the stem tissue than the lesions underneath the bark (Fig 5e). Some of the fungi caused severe rotting of the wood near the inoculation site (Fig 5f) and this resembled the wood rot observed in the trunks of recently fallen mature baobab trees (Fig 6).

Variation in the lesion lengths was observed associated with inoculations of different isolates of the same species (Fig 7). Both isolates of L. pseudotheobromae, as well as the L. iraniensis isolate, caused lesions that were significantly $(\mathrm{p}<0.001)$ larger than those of the controls. Two of the three L. euphorbiicola isolates tested caused significant lesions while the third isolate (CMW 33327) did not. Most of the L. mahajangana isolates gave rise to only small lesions or did not result in lesion development. An exception was found with isolates CMW 36172 and CMW 36212 that were associated with lesions significantly larger than those of the controls. 

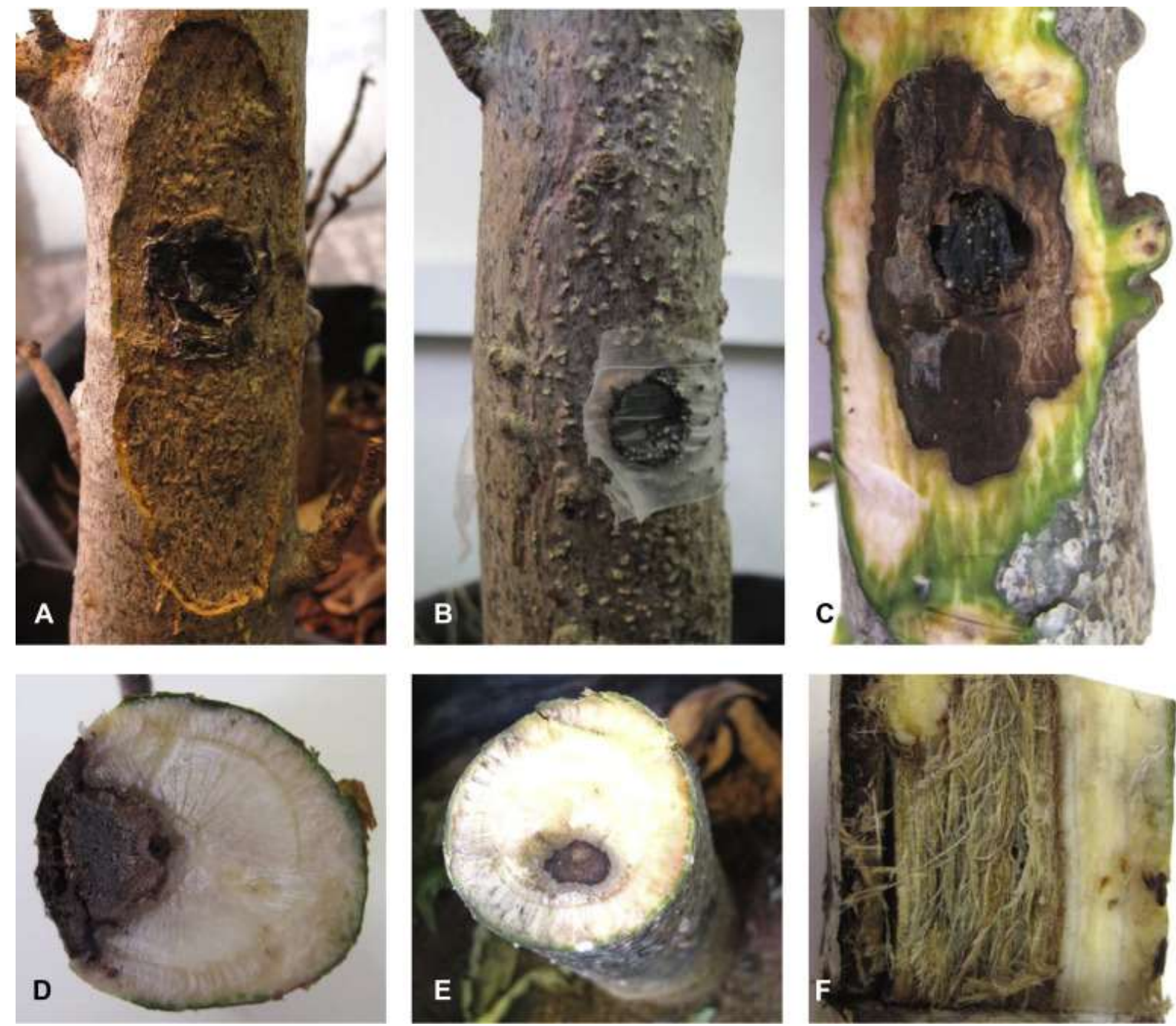

Fig 5 (a) Sunken lesions around inoculation site, three weeks after inoculation with Lasiodiplodia isolate on baobab trees, (b) sporulation by Lasiodiplodia on bark and parafilm, (c) lesion under bark after six weeks, (d) lesion extending to middle of stem, (e) lesion inside stem extending past external lesion and (f) rotting symptom inside stem 


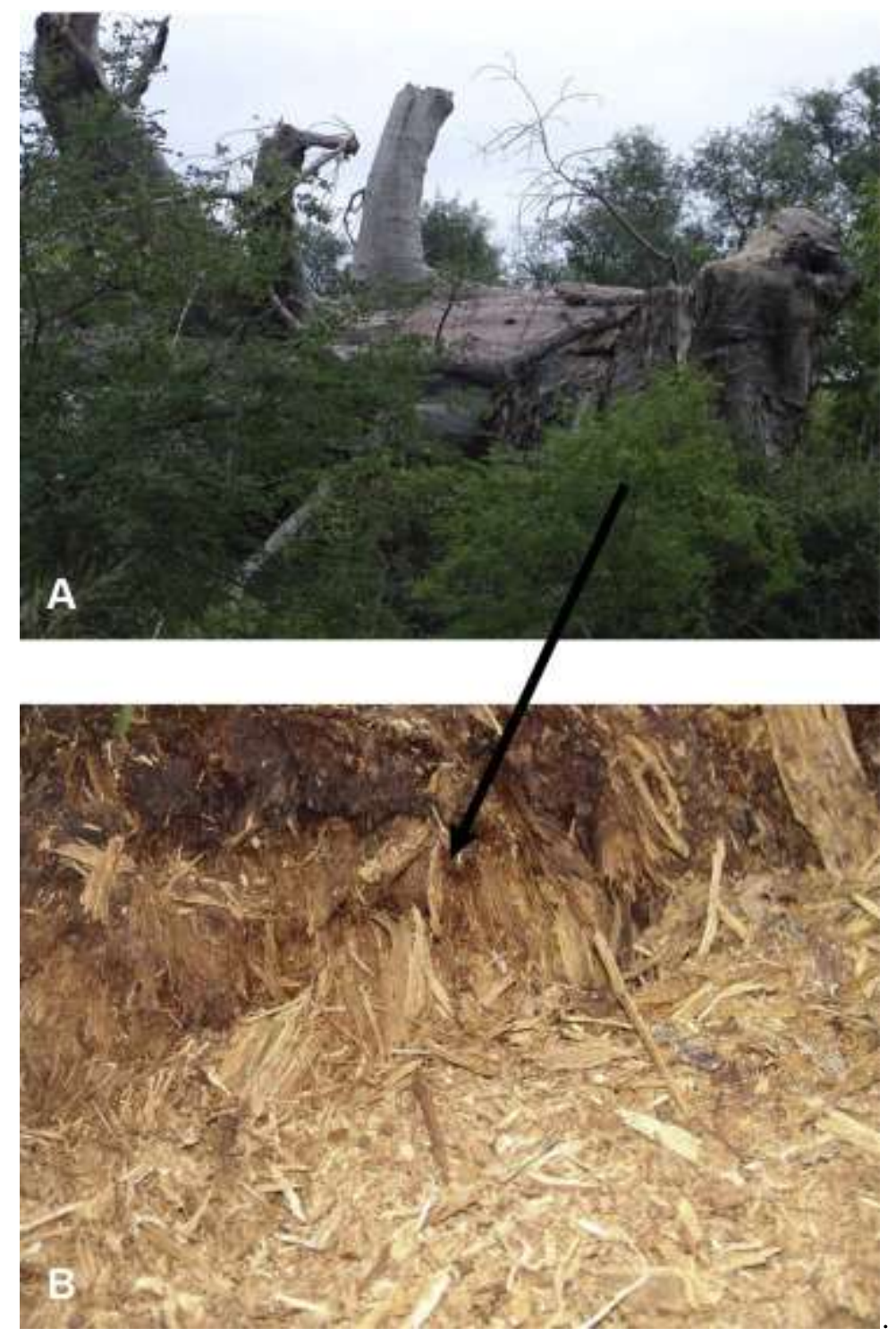

Fig 6 Baobab tree in KNP that had recently collapsed (a) main stem broken due to rotten wood inside, (b) loose fibres of rotten wood inside main stem. 


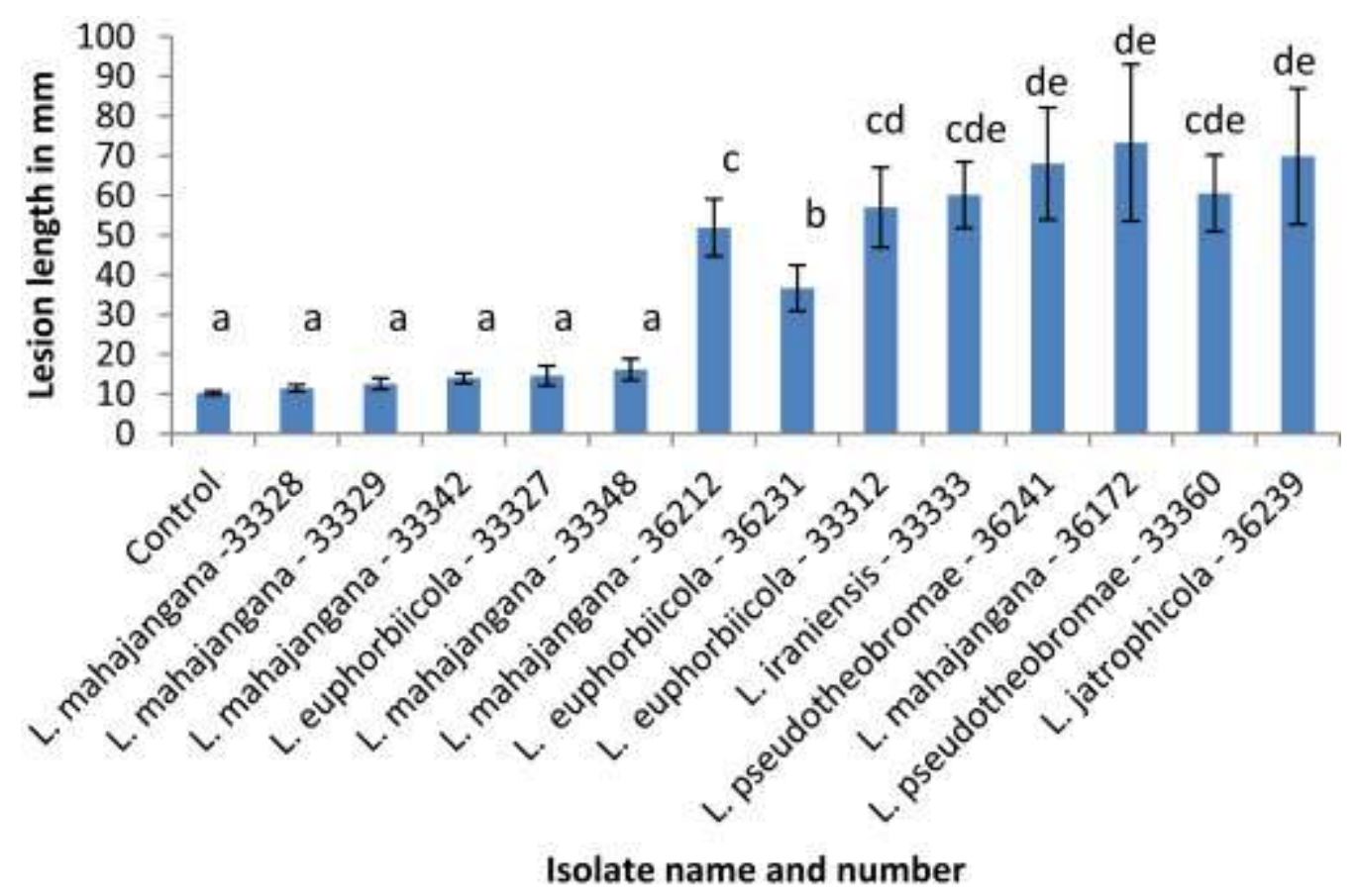

Fig 7 Mean lesion length ( $\mathrm{mm}$ ) of pathogenicity trial with Lasiodiplodia isolates on young baobab (Adansonia) trees. Significant differences $(\mathrm{p}<001)$ are indicated with different letters above the bars.

\section{Discussion}

Phylogenetic inference based on four gene regions made it possible to identify numerous species of Lasiodiplodia occurring on baobabs. Importantly, the results show that several isolates of previously described Lasiodiplodia species, including the ex-type isolates of $L$. brasiliense, L. laeliocattleyae, L. missouriana and L. viticola, as well as a group of isolates from baobab trees, grouped incongruently in trees derived from different loci. This incongruence could be explained only by hybridisation. The described species are, therefore, invalid and they have consequently been designated as the hybrid species L.×brasiliense, L. $\times$ laeliocattleyae, L. $\times$ missouriana, and L. $\times$ viticola. The isolates from baobab trees were identified as the hybrid species L. $\times$ brasiliense and L. $\times$ laeliocattleyae, together with $L$. crassispora, L. euphorbiicola, L. exigua, L. gonubiensis, L. iraniensis, L. mahajangana, L. pseudotheobromae and L. theobromae.

The fact that evidence of hybridisation was found in ex-type as well as other isolates of described Lasiodiplodia species is not surprising. The broad host ranges and endophytic nature of these fungi facilitate their global movement with plant material. This brings related fungi that had speciated in allopatry into contact, which would be ideal for hybrids to form 
becaue these species are expected to not have evolved mating barriers in all cases (Brasier 1995; Brasier 2001). The large numbers of sexual and asexual spores produced by fungi also make successful hybridisation more likely because only a few of the millions of spores produced require a fitness advantage over the parental species. These fungi with new combinations of genes would then be able to outcompete the parental species or occupy a novel niche (Stukenbrock 2016).

The hybrid species and isolates identified in this study showed incongruence between different gene trees. This has also been found in the studies of endophytes of tall fescue grasses (Moon et al. 2004; Schardl and Craven 2003) and Fusarium (O’Donnell et al. 2000). The evidence that at least four of the previously described Lasiodiplodia species are hybrids, emphasises the importance of using multiple loci, and as many isolates as possible, to define cryptic species. In particular, interpretation of tef $1-\alpha$ data must be made with caution and not only in combination with ITS. This is because phylogenies based on the tef $1-\alpha$ locus commonly display incongruence with other gene trees. As part of this study and to facilitate future work, we have also presented a decision tree that can be used to identify other groups of hybrid fungi in the Botryosphaeriaceae.

Our study is not the first to observe hybrids in Lasiodiplodia, but is the first to describe these hybrid species. Sakalidis (2011) reported on Lasiodiplodia isolates that appeared to be hybrids of two different Lasiodiplodia species where Lasiodiplodia hybrid 1 was similar to $L$. pseudotheobromae based on ITS and intermediate between L. parva and $L$. pseudotheobromae based on tef1- $\alpha$. Hybrid 2 was similar to L. citricola based on ITS and intermediate between L. parva and L. citricola based on tef1- $\alpha$. These species were, however, not described.

The 30 isolates considered as hybrids and collected from baobab trees in this study varied in the number of gene regions in which they grouped with different species. Some isolates grouped with L. mahajangana based on two loci and L. euphorbiicola based on the other two loci evaluated. Other isolates showed congruence based on three loci and they grouped with a different species based on only a single locus. It is, therefore, clear that hybrids can easily be overlooked when only one or two loci are used for identification, as has clearly occurred in many of the cases that we have described in this study. This appears to be a common problem in Lasiodiplodia and it is likely also true for other species in the Botryosphaeriaceae. 
The hybrid isolates from baobab trees were classified based on information from four loci. Many hybrids have traditionally been classified based on morphology that was intermediate between that of the parental strains, or changes in pathogenicity (Joly et al. 2006; Newcombe et al. 2000). However, the similar morphology of Lasiodiplodia species and their broad host ranges would make it impossible to use morphology or pathogenicity for hybrid identification. A single locus has been used to infer hybridisation in diploid organisms or where a locus is duplicated (Man in 't Veld et al. 2006; Man in 't Veld et al. 2012; Nielsen and Yohalem 2001). It would appear that only single versions of the loci tested thus far are present in Lasiodiplodia, therefore hybrids cannot be detected in this way. The utilisation of multiple loci is currently the most efficient way to recognise hybrids in Lasiodiplodia.

Lasiodiplodia mahajangana was the species most often isolated from baobabs in Africa and it was isolated from healthy and diseased trees. Interestingly, this was also the species most commonly found on A. gregorii in Australia where it caused lesions in a pathogenicity trial (Sakalidis et al. 2011a). The pathogenicity trials with the African isolates in the present study revealed considerable variation, with only two of the six isolates causing lesions.

Lasiodiplodia mahajangana was isolated from all the countries sampled, and it appears to have a wide host range and worldwide distribution. This species was originally described from Terminalia catappa in Madagascar (Begoude et al. 2010), but has subsequently been reported from various other hosts and countries. Some of the hosts and countries from which it has been collected include A. gregorii, Santalum album, M. indica and Melaleuca sp. in Australia (Sakalidis 2011); Pistacia vera in the USA (Inderbitzin et al. 2010) and Euphorbia ingens in South Africa (Van der Linde et al. 2011).

The second major group of isolates from baobabs clustered with L. euphorbiicola. Isolates of this species were obtained from seven of the nine countries where samples were collected, but not from South Africa and Mozambique. Pathogenicity trials revealed variability in aggressiveness, with one isolate not causing lesions, and two others used in the tests, causing significant lesions on baobab seedlings. Lasiodiplodia euphorbiicola was described from Jatropha curcas in Brazil (Machado et al. 2014) and is closely related to L. parva. Lasiodiplodia euphorbiicola and L. parva are identical based on four loci and differed only by six base pairs based on the tef1- $\alpha$ locus.

Species of Lasiodiplodia that were found in only one country included L. gonubiensis collected only in Mozambique, and L. crassispora isolated from diseased and healthy trees in 
Senegal. Although these species were found on baobab trees infrequently, they have been reported from different hosts in other countries and continents. For example, L. crassispora was described from S. album in Australia (Burgess et al. 2006). Consequently these species also have broad host and distribution ranges and may be present on baobab trees more often than is evident from this study.

Several isolates in the present study clustered with L. iraniensis and were found from Benin, Cameroon, Madagascar Senegal and South Africa. Most of the isolates were obtained from healthy trees, with the exceptions being those from Senegal and Benin. In a survey of fungi occurring on baobabs trees in Australia, Sakalidis et al. (2011a) found that L. iraniensis was the most aggressive species. The L. iraniensis isolate included in the current pathogenicity trial also gave rise to significant lesions. However, no L. iraniensis were isolated from the population of baobab trees with the highest incidence of disease observed in this study (Tsumkwe area in Namibia); only L. mahajangana and L. euphorbiicola were found from these trees. Lasiodiplodia iraniensis clearly has a worldwide distribution and wide host range having been described from $M$. indica in Iran and reported on Juglans sp., Citrus sp. and Salvadora persica in the same country (Abdollahzadeh et al. 2010). Lasiodiplodia iraniensis has also been isolated from A. gregorii in Australia (Sakalidis et al. 2011a).

The worldwide occurrence of many of the Lasiodiplodia species in this study suggest that these species are being moved around the world. Botryosphaeriaceae occurring as endophytes in plants are efficient, opportunistic colonisers of plants (Slippers and Wingfield 2007) and Lasiodiplodia is probably being moved with plant material. Our discovery of four hybrid species and many hybrid isolates within Lasiodiplodia, raises concerns that introductions of new species may result in the formation of more hybrids. These hybrids can evolve more rapidly (Brasier 2001) and may be more aggressive or have wider host ranges than the parental species, as was found for both the poplar rust pathogen Melampsora $\times$ columbiana (Newcombe et al. 2000) and Verticillium longisporum, a pathogen of crucifers (Inderbitzin et al. 2011). This emphasises an urgent need to restrict the global movement of plant material (Liebhold et al. 2012; Wingfield et al. 2015).

This study serves as a foundation towards understanding the distribution and role of endophytic Lasiodiplodia on baobabs in Africa. It is not clear whether these fungi play a role in the baobab deaths that have been observed. But the fact that some of the isolates tested caused substantial lesions and severe rotting of the stems, may be linked to the rotting of 
mature trees seen in the field. The global movement and distribution of these fungi deserves further study to fully understand the occurrence of different species in their countries of origin.

\section{Acknowledgements}

We thank members of the Tree Protection Co-operative Programme (TPCP), the NRF-DST Centre of Excellence in Tree Health Biotechnology (CTHB), and the University of Pretoria, South Africa for financial support that made this study possible. We also thank Dr. Aida Cuni Sanchez for providing sample material from Senegal and Benin, Dr. Michael Mbenoun and IRAD in Cameroon for assistance in collections from there, and Dr. Norbert Hahn for assistance in locating and sampling trees in the Limpopo Province. We thank Dr. Pascal Dantu, Ms. Rahajanirina Voninavoko and Mr. Emilson Rakotoarisoa of CIRAD in Madagascar for assisting with collections in that country. We also thank the South African National Parks and Kruger National Park for allowing us to sample there and for offering game guards to protect us while sampling. Dr. Lucas Shuttleworth and Mr. James Mehl are thanked for supplying some of the sequence data used.

\section{References}

Abdollahzadeh J, Javadi A, Goltapeh EM, Zare R, Phillips AJL, 2010. Phylogeny and morphology of four new species of Lasiodiplodia from Iran. Persoonia 25: 1-10.

Alves A, Crous PW, Correia A, Phillips AJL, 2008. Morphological and molecular data reveal cryptic speciation in Lasiodiplodia theobromae. Fungal Diversity 28: 1-13.

Begoude BAD, Slippers B, Wingfield M, Roux J, 2010. Botryosphaeriaceae associated with Terminalia catappa in Cameroon, South Africa and Madagascar. Mycological Progress 9: 101-123.

Brasier C, 1995. Episodic selection as a force in fungal microevolution, with special reference to clonal speciation and hybrid introgression. Canadian Journal of Botany 73: $1213-1221$.

Brasier CM, 2001. Rapid evolution of introduced plant pathogens via interspecific hybridization: Hybridization is leading to rapid evolution of Dutch elm disease and other fungal plant pathogens. BioScience 51: 123-133. 
Burgess TI, Barber PA, Mohali S, Pegg G, de Beer W, Wingfield MJ, 2006. Three new Lasiodiplodia spp. from the tropics, recognized based on DNA sequence comparisons and morphology. Mycologia 98: 423-435.

Carbone I, Kohn LM, 1999. A method for designing primer sets for speciation studies in filamentous ascomycetes. Mycologia 91: 553-556.

Chen S, Li G, Liu F, Michailides TJ, 2015. Novel species of Botryosphaeriaceae associated with shoot blight of pistachio. Mycologia 107: 780-792.

Crous PW, Rong IH, Wood A, Lee S, Glen H, Botha W, Slippers B, de Beer WZ, Wingfield MJ, Hawksworth DL, 2006. How many species of fungi are there at the tip of Africa? Studies in Mycology 55: 13-33.

Damm U, Crous PW, Fourie PH, 2007. Botryosphaeriaceae as potential pathogens of Prunus species in South Africa, with descriptions of Diplodia africana and Lasiodiplodia plurivora sp. nov. Mycologia 99: 664-680.

Darriba D, Taboada G, Doallo R, Posada D, 2012. jModelTest 2: more models, new heuristics and parallel computing. Nature Methods 9: 772.

De Vos L, Van der Nest MA, Van der Merwe NA, Myburg AA, Wingfield MJ, Wingfield BD, 2011. Genetic analysis of growth, morphology and pathogenicity in the F1 progeny of an interspecific cross between Fusarium circinatum and Fusarium subglutinans. Fungal Biology 115: 902-908.

Doilom M, Shuttleworth LA, Roux J, Chukeatirote E, Hyde KD, 2015. Botryosphaeriaceae associated with Tectona grandis (teak) in northern Thailand. Phytotaxa 233: 1-26.

Felsenstein J, 2005. PHYLIP (Phylogeny Inference Package) v.3.6. Distributed by the author, Department of Genome Sciences, University of Washington, Seattle.

Gardes M, Bruns TD, 1993. ITS primers with enhanced specificity for basidiomycetes application to the identification of mycorrhizae and rusts. Molecular Ecology 2: 113118.

Glass N, Donaldson G, 1995. Development of primer sets designed for use with the PCR to amplify conserved genes from filamentous ascomycetes. Applied and Environmental Microbiology 61: 1323-1330.

Guindon S, Gascuel O, 2003. A simple, fast and accurate method to estimate large phylogenies by maximum-likelihood. Systematic Biology 52: 696-704.

Husson C, Aguayo J, Revellin C, Frey P, Ioos R, Marçais B, 2015. Evidence for homoploid speciation in Phytophthora alni supports taxonomic reclassification in this species complex. Fungal Genetics and Biology 77: 12-21. 
Inderbitzin P, Bostock RM, Trouillas FP, Michailides TJ, 2010. A six locus phylogeny reveals high species diversity in Botryosphaeriaceae from California almond. Mycologia 102: 1350-1368.

Inderbitzin P, Davis RM, Bostock RM, Subbarao KV, 2011. The ascomycete Verticillium longisporum is a hybrid and a plant pathogen with an expanded host range. PLoS ONE 6: e18260.

Ismail AM, Cirvilleri G, Polizzi G, Crous PW, Groenewald JZ, Lombard L, 2012. Lasiodiplodia species associated with dieback disease of mango (Mangifera indica) in Egypt. Australasian Plant Pathology 41: 649-660.

Joly DL, Langor DW, Hamelin RC, 2006. Molecular and morphological evidence for interspecific hybridization between Cronartium ribicola and C. comandrae on Pinus flexilis in southwestern Alberta. Plant Disease 90: 1552-1552.

Liebhold AM, Brockerhoff EG, Garrett LJ, Parke JL, Britton KO, 2012. Live plant imports: the major pathway for forest insect and pathogen invasions of the US. Frontiers in Ecology and the Environment 10: 135-143.

Linaldeddu BT, Deidda A, Scanu B, Franceschini A, Serra S, Berraf-Tebbal A, Boutiti MZ, Jamâa MB, Phillips AJ, 2015. Diversity of Botryosphaeriaceae species associated with grapevine and other woody hosts in Italy, Algeria and Tunisia, with descriptions of Lasiodiplodia exigua and Lasiodiplodia mediterranea sp. nov. Fungal Diversity 71: $201-214$.

Liu J-K, Phookamsak R, Doilom M, Wikee S, Li Y-M, Ariyawansha H, Boonmee S, Chomnunti P, Dai D-Q, Bhat J et al., 2012. Towards a natural classification of Botryosphaeriales. Fungal Diversity 57: 149-210.

Machado AR, Pinho DB, Pereira OL, 2014. Phylogeny, identification and pathogenicity of the Botryosphaeriaceae associated with collar and root rot of the biofuel plant Jatropha curcas in Brazil, with a description of new species of Lasiodiplodia. Fungal Diversity 67: 231-247.

Man in 't Veld WA, Cock AWAM, Summerbell RC, 2006. Natural hybrids of resident and introduced Phytophthora species proliferating on multiple new hosts. European Journal of Plant Pathology 117: 25-33.

Man in 't Veld WA, Rosendahl KCHM, Hong C, 2012. Phytophthora xserendipita sp. nov. and $P . \times$ pelgrandis, two destructive pathogens generated by natural hybridization. Mycologia 104: 1390-1396. 
Marques M, Lima N, de Morais M, Jr., Barbosa M, Souza B, Michereff S, Phillips AL, Câmara MS, 2013. Species of Lasiodiplodia associated with mango in Brazil. Fungal Diversity 61: 181-193.

Möller E, Bahnweg G, Sandermann H, Geiger H, 1992. A simple and efficient protocol for isolation of high molecular weight DNA from filamentous fungi, fruit bodies, and infected plant tissues. Nucleic Acids Research 20: 6115.

Moon CD, Craven KD, Leuchtmann A, Clement SL, Schardl CL, 2004. Prevalence of interspecific hybrids amongst asexual fungal endophytes of grasses. Molecular Ecology 13: 1455-1467.

Netto MB, Assunção I, Lima GA, Marques M, Lima W, Monteiro JA, de Queiroz Balbino V, Michereff S, Phillips AL, Câmara MS, 2014. Species of Lasiodiplodia associated with papaya stem-end rot in Brazil. Fungal Diversity 67: 127-141.

Newcombe G, Stirling B, McDonald S, Bradshaw H, 2000. Melampsora ×columbiana, a natural hybrid of M. medusae and M. occidentalis. Mycological Research 104: 261274.

Nielsen K, Yohalem DS, 2001. Origin of a polyploid Botrytis pathogen through interspecific hybridization between Botrytis aclada and B. byssoidea. Mycologia 93: 1064-1071.

Nirenberg HI, Gerlach WF, Gräfenhan T, 2009. Phytophthora ×pelgrandis, a new natural hybrid pathogenic to Pelargonium grandiflorum Hort. Mycologia 101: 220-231.

O’Donnell K, Kistler HC, Tacke BK, Casper HH, 2000. Gene genealogies reveal global phylogeographic structure and reproductive isolation among lineages of Fusarium graminearum, the fungus causing wheat scab. PNAS 97: 7905-7910.

Olson $\AA$, Stenlid J, 2002. Pathogenic fungal species hybrids infecting plants. Microbes and Infection 4: 1353-1359.

Pavlic D, Slippers B, Coutinho T, Gryenhout M, Wingfield M, 2004. Lasiodiplodia gonubiensis sp. nov., a new Botryosphaeria anamorph from native Syzygium cordatum in South Africa. Studies in Mycology 50: 313-322.

Pavlic D, Slippers B, Coutinho TA, Wingfield MJ, 2009. Multiple gene genealogies and phenotypic data reveal cryptic species of the Botryosphaeriaceae: A case study on the Neofusicoccum parvum/N. ribis complex. Molecular Phylogenetics and Evolution 51: 259-268.

Pavlic D, Wingfield MJ, Barber P, Slippers B, Hardy GESJ, Burgess TI, 2008. Seven new species of the Botryosphaeriaceae from baobab and other native trees in Western Australia. Mycologia 100: 851-866. 
Phillips AJL, Alves A, Abdollahzadeh J, Slippers B, Wingfield MJ, Groenewald JZ, Crous PW, 2013. The Botryosphaeriaceae: genera and species known from culture. Studies in Mycology 76: 51-167.

Prasher IB, Singh G, 2014. Lasiodiplodia indica - A new species of coelomycetous mitosporic fungus from India. Kavaka 43: 64-69.

Punithalingam E, 1976. Botryodiplodia theobromae vol 519. Kew: Commonwealth Mycological Institute, Surrey, England.

Rodríguez-Gálvez E, Guerrero P, Barradas C, Crous PW, Alves A, 2016. Phylogeny and pathogenicity of Lasiodiplodia species associated with dieback of mango in Peru. Fungal Biology http://dx.doi.org/10.1016/j.funbio.2016.06.004:

Ronquist F, Huelsenbeck JP, 2003. MrBayes 3: Bayesian phylogenetic inference under mixed models. Bioinformatics 19: 1572-1574.

Roux J, 2002. Baobab mortality in the Mesina Nature Reserve - A pilot study. Tree Protection Co-operative Programme (TPCP), University of Pretoria, Pretoria, South Africa.

Sakalidis M, 2011. Investigation and analysis of taxonomic irregularities within the Botryosphaeriaceae. Murdoch University.

Sakalidis ML, Hardy GES, Burgess TI, 2011a. Endophytes as potential pathogens of the baobab species Adansonia gregorii: a focus on the Botryosphaeriaceae. Fungal Ecology 4: 1-14.

Sakalidis ML, Hardy GESJ, Burgess TI, 2011b. Use of the Genealogical Sorting Index (GSI) to delineate species boundaries in the Neofusicoccum parvum-Neofusicoccum ribis species complex. Molecular Phylogenetics and Evolution 60: 333-344.

Schardl C, Craven K, 2003. Interspecific hybridization in plant-associated fungi and oomycetes: a review. Molecular Ecology 12: 2861-2873.

Schoch CL, Robbertse B, Robert V, Vu D, Cardinali G, Irinyi L, Meyer W, Nilsson RH, Hughes K, Miller AN, 2014. Finding needles in haystacks: linking scientific names, reference specimens and molecular data for fungi. Database 2014: 1-21.

Slippers B, Fourie G, Crous PW, Coutinho TA, Wingfield BD, Wingfield MJ, 2004. Multiple gene sequences delimit Botryosphaeria australis sp. nov. from B. lutea. Mycologia 96: 1030-1041.

Slippers B, Roux J, Wingfield MJ, Van der Walt FJJ, Jami F, Mehl JWM, Marais G, 2014. Confronting the constraints of morphological taxonomy in the Botryosphaeriales. Persoonia 33: 155-168. 
Slippers B, Wingfield MJ, 2007. Botryosphaeriaceae as endophytes and latent pathogens of woody plants: diversity, ecology and impact. Fungal Biology Reviews 21: 90-106.

Stukenbrock EH, 2016. The role of hybridization in the evolution and emergence of new fungal plant pathogens. Phytopathology 106: 104-112.

Swofford D, 2003. PAUP (Phylogenetic Analysis Using Parsimony), 4.0b10 edn. Sinauer Associates, Massachusetts.

Taylor JW, Jacobson DJ, Kroken S, Kasuga T, Geiser DM, Hibbett DS, Fisher MC, 2000. Phylogenetic Species Recognition and species concepts in fungi. Fungal Genetics and Biology 31: 21-32.

Trakunyingcharoen T, Lombard L, Groenewald JZ, Cheewangkoon R, To-anun C, Crous PW, 2015. Caulicolous Botryosphaeriales from Thailand. Persoonia 34: 87-99.

Urbez-Torres J, Peduto F, Striegler RK, Urrea-Romero KE, Rupe JC, Cartwright RD, Gubler WD, 2012. Characterization of fungal pathogens associated with grapevine trunk diseases in Arkansas and Missouri. Fungal Diversity 52: 169-189.

Úrbez-Torres JR, Gubler WD, 2009. Pathogenicity of Botryosphaeriaceae species isolated from grapevine cankers in California. Plant Disease 93: 584-592.

Van der Linde JA, Six DL, Wingfield MJ, Roux J, 2011. Lasiodiplodia species associated with dying Euphorbia ingens in South Africa. Southern Forests 73: 165-173.

White TJ, Bruns T, Lee S, Taylor J, 1990. Amplification and direct sequencing of fungal ribosomal RNA genes for phylogenetics. In: Innis AM, Gelfard DH, Snindky JJ, White TJ (eds) PCR Protocols: A Guide to Methods and Applications. Academic Press, San Diego, pp 315-322.

Wingfield MJ, Brockerhoff EG, Wingfield BD, Slippers B, 2015. Planted forest health: The need for a global strategy. Science 349: 832-836.

Yildiz A, Benlioglu K, Benlioglu H, 2014. First report of strawberry dieback caused by Lasiodiplodia theobromae. Plant Disease 98: 1579-1579. 